\title{
Production and characterisation of adsorbents synthesised by hydrothermal carbonisation of biomass wastes
}

\author{
E. Danso-Boateng ${ }^{1}$ (D) A. S. Mohammed ${ }^{2} \cdot$ G. Sander ${ }^{2}$ A. D. Wheatley ${ }^{2} \cdot$ E. Nyktari $^{3} \cdot$ I. C. Usen $^{4}$
}

Received: 31 October 2020 / Accepted: 25 January 2021 / Published online: 2 February 2021

(c) The Author(s) 2021 OPEN

\begin{abstract}
Surface structure and chemical properties of adsorbents are important factors required to understand the mechanism of adsorption. The purpose of this study was to produce hydrochars from biomass using hydrothermal carbonisation (HTC) and to analyse their sorption capacities. The biomass used in this study were coco-peat (CP), coconut shell (CS), eggshell (ES), rice husk (RH) and lemon peel (LP). The operating conditions for HTC were $200^{\circ} \mathrm{C}$ and $20 \mathrm{~h}$ residence time. The characterisation methods consisted of Scanning Electron Microscopy (SEM), Energy Dispersive X-Ray Spectroscopy (EDS), Fourier Transform Infrared Ray (FTIR) Spectroscopy, and Brunauer, Emmett and Teller (BET). The results showed that HTC improved the sorption capacities of the biomass wastes. It was found that hydrochars were crispy and flaky with more micro- and meso-porous structures, indicating that lignin and other components were denatured due to carbonisation. This led to the creation of more active sites for sorption and pollutant binding. The hydrochars showed a percentage increase in carbon content and a decrease in oxygen content with traces of other elements, compared to their corresponding raw biomass. The major functional groups identified were $-\mathrm{OH}$ and $-\mathrm{COOH}$. The surface area of the hydrochars which include CP $\left(2.14 \mathrm{~m}^{2} / \mathrm{g}\right), \mathrm{CS}\left(14.04 \mathrm{~m}^{2} / \mathrm{g}\right), \mathrm{ES}\left(0.50 \mathrm{~m}^{2} / \mathrm{g}\right), \mathrm{RH}\left(15.74 \mathrm{~m}^{2} / \mathrm{g}\right)$, and LP $\left(6.89 \mathrm{~m}^{2} / \mathrm{g}\right)$ were significantly improved compared with those of the raw biomass. The study showed that the hydrochars produced from the biomass wastes have the potential to be used as adsorbents.
\end{abstract}

Keywords Adsorbent characteristics · Adsorption · Biosorbents $\cdot$ Hydrochar $\cdot$ Surface analysis

\section{Introduction}

Micro and macro structural properties, elemental composition, functional groups and surface area, pore volume as well as pore size are important factors required in order to understand the intrinsic properties that underpin adsorption of organic and inorganic pollutants onto material surface. Utilising hydrochars of biomass waste for the removal of environmental contaminants such as heavy metals from industrial wastewater has become a technology with huge research potentials in recent years [1]. This research provides a simple, efficient, sustainable, and affordable technique for producing adsorbents from biomass waste through a thermochemical process called hydrothermal carbonisation (HTC).

Over the years, conventional wastewater treatment technologies have been used for the removal of contaminants from wastewaters. Typical examples include chemical precipitation, ion-exchange, coagulation and membrane filtration [2]. However, these technologies have proven to be more inimical than being beneficial $[3,4]$. Apart from adsorption, most of these technologies require complex designs, high procurement, operational and maintenance costs, as well as generating secondary

E. Danso-Boateng, e.danso-boateng@leeds.ac.uk| 'School of Chemical and Process Engineering, University of Leeds, Leeds LS2 9JT, UK. ${ }^{2}$ School of Architecture, Building and Civil Engineering, Loughborough University, Loughborough LE11 3TU, UK. ${ }^{3}$ Department of Chemical Engineering, Loughborough University, Loughborough LE11 3TU, UK. ${ }^{4}$ Department of Chemistry, Loughborough University, Loughborough LE11 3TU, UK. 
toxic wastes which require additional costs for treatment [5].

The search for a sustainable and cost-effective technology for wastewater treatment has gained scientific interest in recent times; with particular attention being attributed to the application of sustainable and lowcost sorbents due to their abundance and ease of availability $[2,6]$. However, a common disadvantage for raw adsorbents is the release of organic components that may cause secondary pollution and oxygen reduction in water [7]. Carbonisation or charring has been proposed as the technique to overcome these problems [8].

Over the years, pyrolysis has been the most common conventional thermal method for charring natural resources and biomass wastes $[9,10]$. The process requires elevated temperatures above $400{ }^{\circ} \mathrm{C}$ in the absence of oxygen, to produce biochar, which is mostly followed by an activation stage at temperatures above $800^{\circ} \mathrm{C}$ to change the physical and chemical phase of the organic material in order to produce 'activated carbon' [11]. For decades, activated carbon has proven to be very effective in the removal of organic and inorganic contaminants in the food industry and wastewater treatment plants. They are also used in the purification of sugar; decolouration of syrups, wine, vinegar, removal of methylene blue and other types of dyes [9]. However, the application of activated carbon is limited by the high production cost partly due to the pyrolysis process and the treatment to obtain the activated carbon [12]. This limitation has led into research for a simpler and costeffective technique to carbonise biomass waste.

One process that transforms biomass waste into possible low-cost adsorbents is hydrothermal carbonisation (HTC). HTC is a thermochemical pathway, in which biomass is heated between 180 and $250^{\circ} \mathrm{C}$ in a closed vessel at a self-increasing pressure to produce a deep brown carbonaceous solid, called 'hydrochar' $[8,13]$. The advantage of HTC over a conventional pyrolysis process is that; it is operated at relatively moderate temperatures. Also, in HTC, the feedstock does not require pre-drying, which reduces the production costs compared to pyrolysis [8]. Furthermore, apart from the solid (hydrochar), HTC also generates water and fewer volatile organics in the gaseous phase $[13,14]$. Unlike raw biomass, majority of the organic components are transferred to the liquid phase [14].

Previous studies suggest that hydrochars have abundance of surface oxygenated functional groups (OFGs) and carbonyl groups [15-19], and have increased surface reactivity over biochars [20]. However, production and characterisation of hydrochars for use as adsorbents are relatively in the developing phase. Also, studies into hydrochars from the biomass materials used in this study are limited; hence, effective utilisation of such hydrochars as adsorbents require further study of their surface structure and chemical properties.

The objective of this study, therefore, is to examine the sorption characteristics of hydrochars produced from abundant waste biomass (eggshells, coco-peat, coconut shell, lemon peels, and rice husk) using: (i) surface morphology; (ii) elemental composition; (iii) functional groups; and (iv) surface area, pore volume and size. The sorption characteristics of the hydrochars will be compared to their corresponding raw biomass.

\section{Materıals and methods}

\subsection{Raw materials}

The materials used in this study were obtained locally; the eggshells were from the University kitchen; the lemon fruits from a street market; the coconuts from a supermarket in Loughborough; the coco-peat was purchased from Fertile Fibre, Withington Hereford; and rice husks purchased from E-Coco Products, Tewkesbury, all in the UK.

\subsubsection{Biomass preparation}

The coco-peat and rice husk were shredded and ground with a kitchen blender before being thoroughly washed with deionised water until a neutral $\mathrm{pH}$ was obtained. Due to the hardness of coconut shell, a hammer was initially used to break the shells into pieces which were then crushed in a cutting mill (Fritsch-Pulverisette-15). A commercial grinder was used to reduce the particle sizes; to obtain a ground coconut shell which was then washed with clean tap water and rinsed with deionised water. The lemons were manually peeled and cut into pieces and ground; eggshells were initially crushed by hand, then milled using a blender before being washed with detergent to remove impurities followed by rinsing with tap and deionsed water. The biomass wastes were initially dried at $60^{\circ} \mathrm{C}$ for $24 \mathrm{~h}$ and subjected to further drying at a temperature of $105^{\circ} \mathrm{C}$ before size separation by a set of 3 nested British Standard (B.S.) sieves. The bottom pan collects finer particles of the decreasing diameter openings. Manual agitation was used to pass sufficient quantity of the desired particle sizes of $1.18 \mathrm{~mm}, 850 \mu \mathrm{m}$ and $600 \mu \mathrm{m}$. These samples were then stored in labelled airtight plastic containers and stored in a cold room at $4{ }^{\circ} \mathrm{C}$ before the characterisation analysis and hydrochar production.

\subsection{Experimental method}

Production of the hydrochars using HTC was conducted by mixing the ground biomass ( $600 \mu \mathrm{m}$ average particle 
size) with deionised water in a non-stirred $250 \mathrm{~mL}$ polytetrafluoroethylene (PTFE) Teflon vessel (suitable for thermal pressure reactions). This was used in a stainless steel batch temperature/pressure reactor (Berghoff BR-300, Berghoff $\mathrm{GmbH}$, Germany). The solids concentration varied between $7.0 \%(\mathrm{wt})$ and $33.3 \%(\mathrm{wt})$ and was up to a total volume of $200 \mathrm{ml}$, depending on the biomass type. The various biomass used had variable weights or densities and thus occupied different volumes in the vessel. For instance, the dry solids content for coco-peat was $7 \%$, while rice husk and lemon peel were $20 \%$; eggshell and coco-shell were $33.3 \%$.

HTC was carried out at a temperature of $200{ }^{\circ} \mathrm{C}$ for a reaction time of $20 \mathrm{~h}$ for all types of biomass; it took approximately $1 \mathrm{~h}$ of heating time to reach the reaction temperature. After carbonisation, the reactor was cooled to room temperature before uncapping the lid to vent the gas phase produced during the process. The carbonised materials were then dewatered from the liquid phase using a Whatman filter Paper No. 1 (11 $\mu$ m pore size) to obtain the hydrochar. The hydrochar was washed with methanol during the filtration to remove the organic components followed by deionised water and subsequently oven-drying. Finally, each dried hydrochar was stored in a labelled air-tight plastic bag and stored at $4{ }^{\circ} \mathrm{C}$ for further analysis. Figure 1 summaries the HTC apparatus and method.

\subsection{Characterisation methods}

The analytical techniques included: (i) Scanning Electron Microscopy (SEM); (ii) Energy Dispersive X-Ray Spectroscopy (EDS); (iii) Brunauer, Emmett and Teller (BET); and (iv) Fourier Transformed Infrared Red (FTIR) spectroscopy.

\subsubsection{Scanning electron microscopy (SEM)}

The surface morphology of each raw biomass and its corresponding hydrochar was determined by an SEM analyser (LEO1530VP FEG-SEM, Carl Zeiss, Germany), operated at $5 \mathrm{kV}$. A thin layer of each specimen was coated with $\mathrm{Au}-\mathrm{Pd}$ in a Hummer 6.2 sputtering system purged with $\mathrm{N}_{2}$ gas and operated at 20 millitorrs, $5 \mathrm{~V}$ and $15 \mathrm{~mA}$ for $5 \mathrm{~min}$. A pre-set working distance was adjusted between 15.0-18.5 mm to capture images at 100x, 500x, 1000x, $5000 \times$ and $10,000 \times$ magnifications. The images with clearest features were selected for EDS analysis of the raw biomass and their hydrochars. After the SEM analysis, the

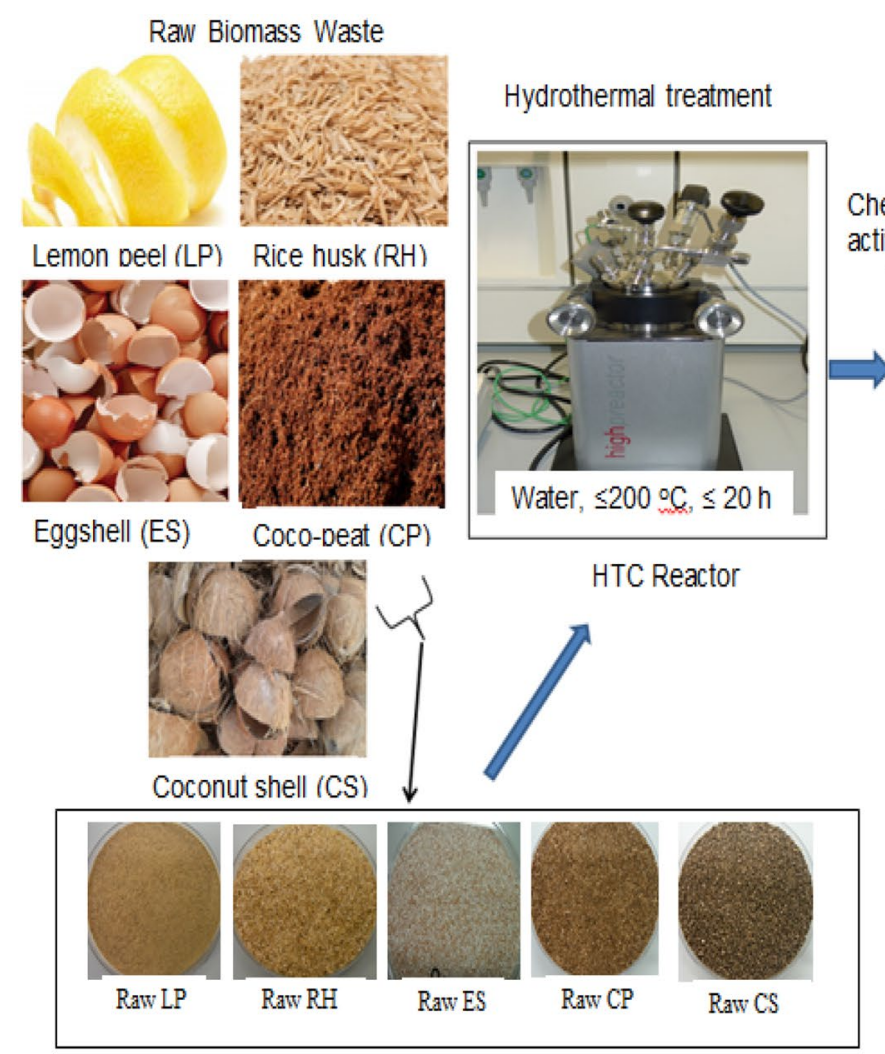

Raw ground samples

Fig. 1 A graphical illustration of the hydrothermal carbonisation process 
surface elemental compositions were analysed using EDS (X-max. $80 \mathrm{~mm}^{2}$ Detector, Oxford Instruments, UK) and microanalysis software (Aztec EDS/EBSD, Oxford Instruments, UK) having a Truemap capability. The working distance (WD) used was $8.5 \mathrm{~mm}$, and target voltage (EHT) of $20 \mathrm{kV}$, at preset aperture of $60 \mu \mathrm{m}$ and beam current of 2.0 $\mathrm{nA}$ as recommended by [21]. All EDS measurements were performed in triplicate.

\subsubsection{Elemental composition}

Carbon $(\mathrm{C})$, hydrogen $(\mathrm{H})$ and nitrogen $(\mathrm{N})$ contents of the raw biomass and hydrochars were also analysed in triplicate using a CHN Analyser (CE-440 Elemental Analyzer, Exeter Analytical Inc., UK), according to ASTM method D5373-08 [22].

\subsubsection{Surface area, pore volume and pore size determination using BET}

Measurements of specific surface areas, pore volumes and pore sizes of the raw materials and hydrochars were performed using a BET Micrometric analyser (TriStar 3000 V6.05 A, Micromeritics Instrument Corporation, USA). For the analysis; $1.6546 \mathrm{~g}$ (coconut shell), $0.3189 \mathrm{~g}$ (coco-peat), $5.8527 \mathrm{~g}$ (eggshell), $1.0391 \mathrm{~g}$ (lemon peel) and $1.1147 \mathrm{~g}$ (rice husk) were independently weighed and poured into a sample holder on the analyser and kept under liquid nitrogen $\left(\mathrm{N}_{2}\right)$ at a temperature of $196.15^{\circ} \mathrm{C}$. The samples were degassed in a vacuum set at a heating rate of $10^{\circ} \mathrm{C} / \mathrm{min}$ up to a temperature of $110^{\circ} \mathrm{C}$, and then kept overnight for $16 \mathrm{~h}$ by following the method described by Pilon et al. [23]. The duration for degassing was based on works reported by Pilon et al. [23] and Barrett et al. [24]. The injected gas used for this analysis had a minimum purity of $99.99 \%$ $\mathrm{N}_{2}$ and $99.98 \% \mathrm{CO}_{2}$. The gas uptake calculation at equilibrium pressure values, was corrected for the empty volume calibration or 'blank uptake' measured before or after each test. Every measurement required about $30 \mathrm{~min}$ for analysis in order to produce highly accurate and reliable results. The total volume of $\mathrm{N}_{2}$ adsorbed $\mathrm{V}_{\text {tot }}\left(\mathrm{cm}^{3} / \mathrm{g}\right)$ was estimated from the volume of adsorbed $\mathrm{N}_{2}$ at relative pressure $p / p^{\circ}$ (equilibrium pressure divided by saturation pressure) which was approximately 0.99 . On the other hand, the pore size $(\mathrm{nm})$ distributions were automatically calculated based on the differential pore volume of BarrettJoyner-Halenda (BJH) adsorption-desorption isotherm [24].

\subsubsection{Fourier transform infrared (FTIR) analysis}

Functional group in each sample was determined using an FTIR analyser (Nicolet iS5, Thermo Fisher Scientific,
USA). The wavenumbers for each sample were measured in the range 4000 to $500 \mathrm{~cm}^{-1}$ using 16 scans. Each sample was ground in a mortar and pestle to produce a fine powder. Approximately, $2 \mathrm{mg}$ of each dried sample was mixed with $300 \mathrm{mg}$ of high purity potassium bromide and then evenly dispersed on a disk before it was placed in a hydraulic press (15 Ton PN 51004599, Perkin Elmer, UK). A load of 10 tons was applied for $1 \mathrm{~min}$ to produce approximately $1 \mathrm{~mm}$ thin layer pellet. A background spectrum was run after wiping the sample platform without a sample to check how clean the sample platform was. This was repeated before each sample was analysed.

\section{Results and discussion}

\subsection{SEM of raw biomass and hydrochar}

\subsubsection{SEM of eggshell}

Figure 2(a) and (b) show the surface texture of a raw eggshell magnified at $100 \times$ and $1000 \times$ respectvely; while 2 (c) and (d) show that of its hydrochar at the same magnifications. The HTC treatment completely changed the structure of the eggshell. It was concluded that the SEM of raw eggshell revealed the protein fibre network, covered by a semi-permeable membrane (albumen). The eggshell is mainly composed of calcium carbonate $\left(\mathrm{CaCO}_{3}\right)$ and magnesium carbonate $\left(\mathrm{MgCO}_{3}\right)$ with some calcium phosphate $\left[\mathrm{Ca}_{3}\left(\mathrm{PO}_{4}\right)_{2}\right]$; but $\mathrm{CaCO}_{3}$ predominate the structure which is about $95-97 \%$ [25-27]. The visible and complex structure of the protein fibres was seen over the entire internal surface structure of the eggshell. However, this arrangement was denatured in the corresponding hydrochar due to the application of heat at $200^{\circ} \mathrm{C}$ for $20 \mathrm{~h}$. The presence of protein matrix observed in raw eggshell resulted in the emission of hydrogen sulphide $\left(\mathrm{H}_{2} \mathrm{~S}\right)$ due to decomposition of the organic components while in solution. These fibres and albumin covering may have contributed to the low total surface area of the eggshell. However, denaturing of the fibre network increased the surface area of the hydrochar (see Sect. 3.3), which could enhance its biosorption capacity and reusability.

\subsubsection{SEM of raw coco-peat}

The SEM images of raw coco-peat, Fig. 3(a) and (b) show uneven exterior surfaces made up of a series of plates which according to Rencoret et al. [28] suggests that coconut fibres are made from the fusion of lignin and pectin compounds. The plate structure was corroborated by the high surface area, but relatively smaller pore size measured in the raw sample by the BET. The HTC treatment 

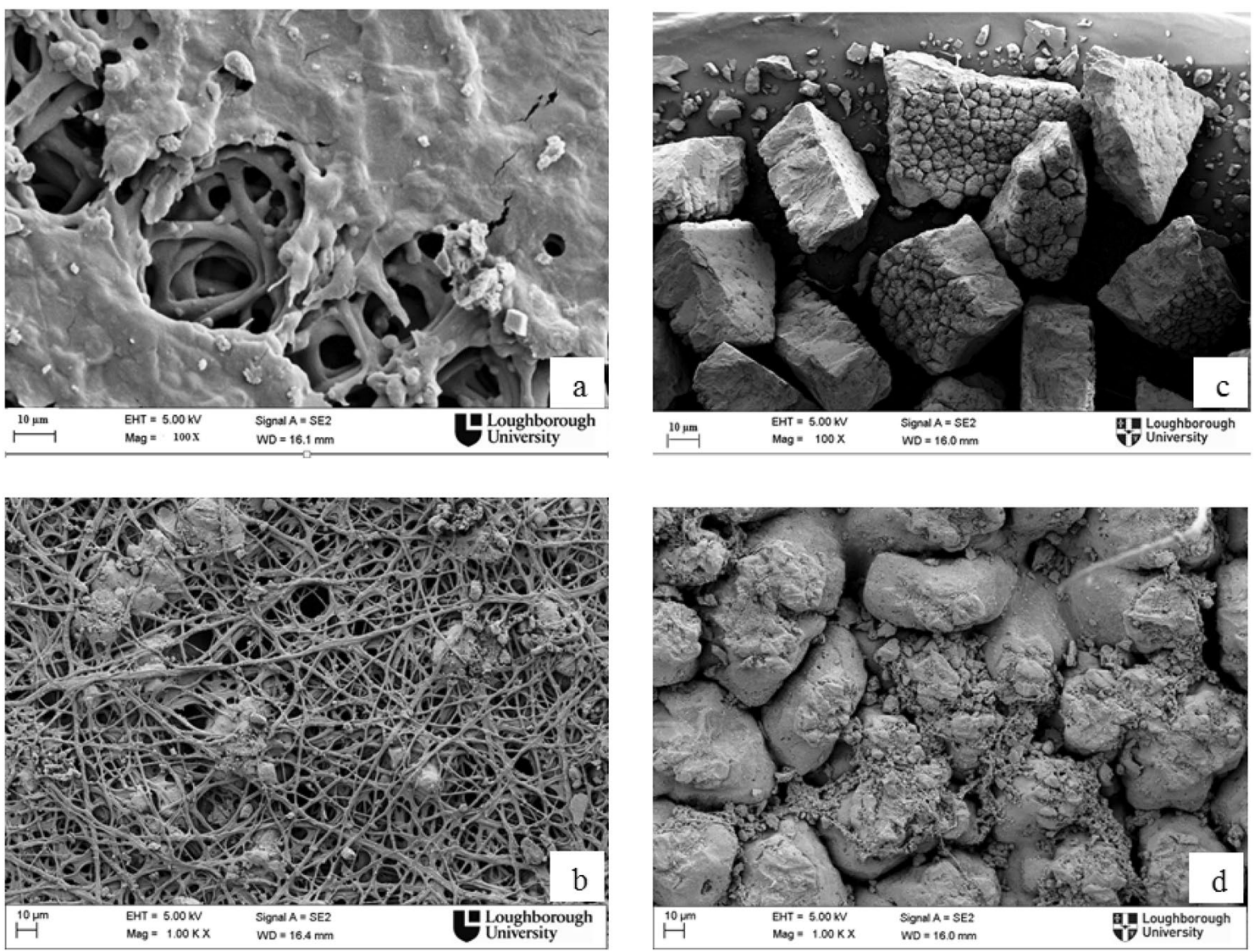

Fig. 2 SEM images of ES at 100× and 1000x: $\mathbf{a}$ and $\mathbf{b}$ raw; $\mathbf{c}$ and $\mathbf{d}$ hydrochar

destroyed the smooth organic plate (lignin and pectin) structures which were converted into the flaky-hollow tubes shapes shown in Fig. 3(c) and (d). These changes contributed to an increase in the surface area of the hydrochar (Sect. 3.3).

\subsubsection{SEM of rice husk}

Rice husks contain structural plant organics such as hemicellulose, crystalline cellulose and lignin but also storage compounds such as starch glucose and bio-oil [28, 29]. The presence of these organics affects the husk total surface area. The SEM micrographs of the raw rice husk shown in Fig. 4(a) and (b) reveals regular symmetrical ridge-like strands of cells which conform to results reported by Kunal et al. [30] and Qiang et al. [31]. The regular cellular structure observed on the exterior husk of the micrographs makes the appearance of this waste different to other biomass wastes. However, heating at $200^{\circ} \mathrm{C}$ for $20 \mathrm{~h}$ changed the organics to produce brittle and flaky hydrochar leaving residual indented plates as shown in Fig. 4 (c) and (d). The surface area and porosity of the hydrochar were increased compared to those of the raw husk (Sect. 3.3).

\subsubsection{SEM of lemon peel}

The scanned images of the raw lemon peel, Fig. 5 (a) and (b) reveals pitted fragmented surfaces at $100 \times$ and smooth plates at the higher magnification. This confirms an earlier study by Kamsonlian [32], who reported SEM images of raw orange peels as smooth and non-porous. Carbonised lemon peel on the other hand, produced flaky and corallike shape structures which clumped together as illustrated in Fig. 5(c) and (d). It was concluded that the lipids, essentials oils and proteins that initially held the structure together have been destroyed.

\subsubsection{SEM of coconut shell}

The SEM analysis of the raw coconut shell is shown in Fig. 6(a) and (b). The surface of the raw coconut shell at the low magnification was irregular and porous, with a grooved plate at the higher magnification. The organic components in raw coconut shell were reported as lignin, hemicellulose and cellulose [33, 34]; which would have been modified by the heat to reduce the organics content. Figure 6(c) and (d) of the coconut hydrochar show 

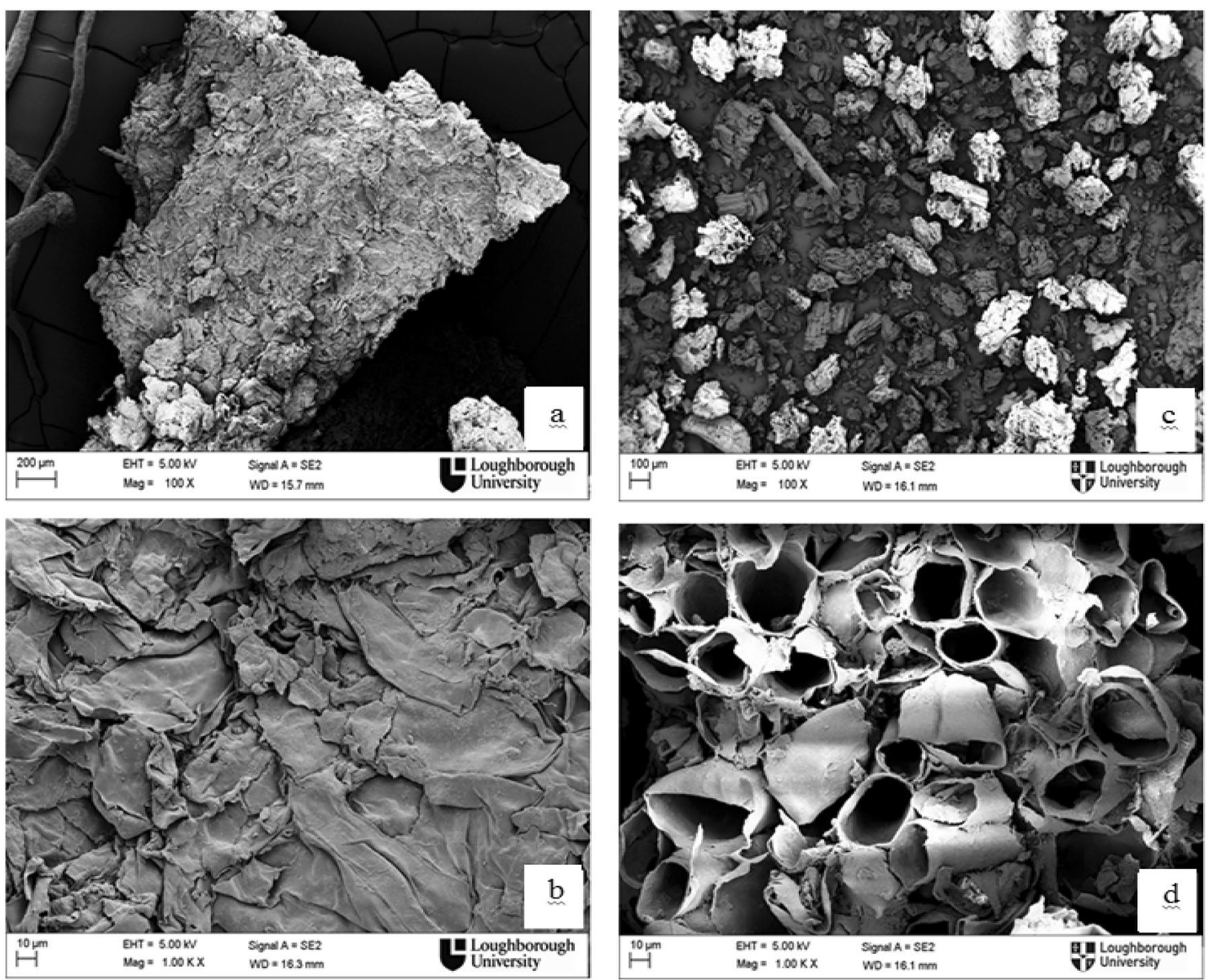

Fig. 3 SEM images of CP at 100 $\times$ and 1000x: $\mathbf{a}$ and $\mathbf{b}$ raw; $\mathbf{c}$ and $\mathbf{d}$ hydrochar

changed surface characteristics with an increased surface area and therefore, improved sorption capacity for adsorption. Generally, the hydrochars have shown an increased surface area, development of finer pores and reduced pore size. It was concluded that these changes would increase the number of actives sites for pollutant binding.

Previous studies have also reported on the changes that HTC has on the structure of biomass although none of these studies have linked the results to the sorption potential of the hydrochars. For instance, Titirici et al. [35] noted that the sponge-like structure of hydrochar was resistant to high applied electron fluxes from the SEM, which they suggested was evidence for a tightly cross-linked carbonaceous structure. Similarly, Heilmann et al. [36] observed that HTC of algae at $200{ }^{\circ} \mathrm{C}$ for $2 \mathrm{~h}$ increased the roughness of the surface, while that from maize silage showed a fibrous structure when carbonised at $230^{\circ} \mathrm{C}$ within $2-10 \mathrm{~h}$ of retention time [37]. A rougher and porous surface was also observed for hydrochar from bamboo carbonised at $220^{\circ} \mathrm{C}$ for $6 \mathrm{~h}$ [38]. The disruption of the colloidal structure and increase in porosity of the carbonised material were found to improve the filterability of sewage sludge hydrochar slurry [39].

\subsection{Elemental composition}

The elemental composition of the raw biomass and corresponding carbonaceous materials by $\mathrm{CHN}$ analysis are shown in Table 1. Carbon content increased in the hydrochar with a corresponding decrease in oxygen and hydrogen contents, except for ES that did not change significantly. As temperature increases, cleavage and cracking of weak oxygen and hydrogen bonds occur during carbonisation, resulting in increasing carbon content of the hydrochars [40]. The increase in carbon content in the hydrochar is the result of densification of the biomass during HTC [14].

The lower $\mathrm{H} / \mathrm{C}$ and $\mathrm{O} / \mathrm{C}$ ratios are caused by dehydration and decarboxylation reactions during HTC [14]. The lower $\mathrm{H} / \mathrm{C}$ and $\mathrm{O} / \mathrm{C}$ ratios in the hydrochars indicate that they have relatively high levels of aromaticity and greater abundance of oxygenated surface functional groups such 

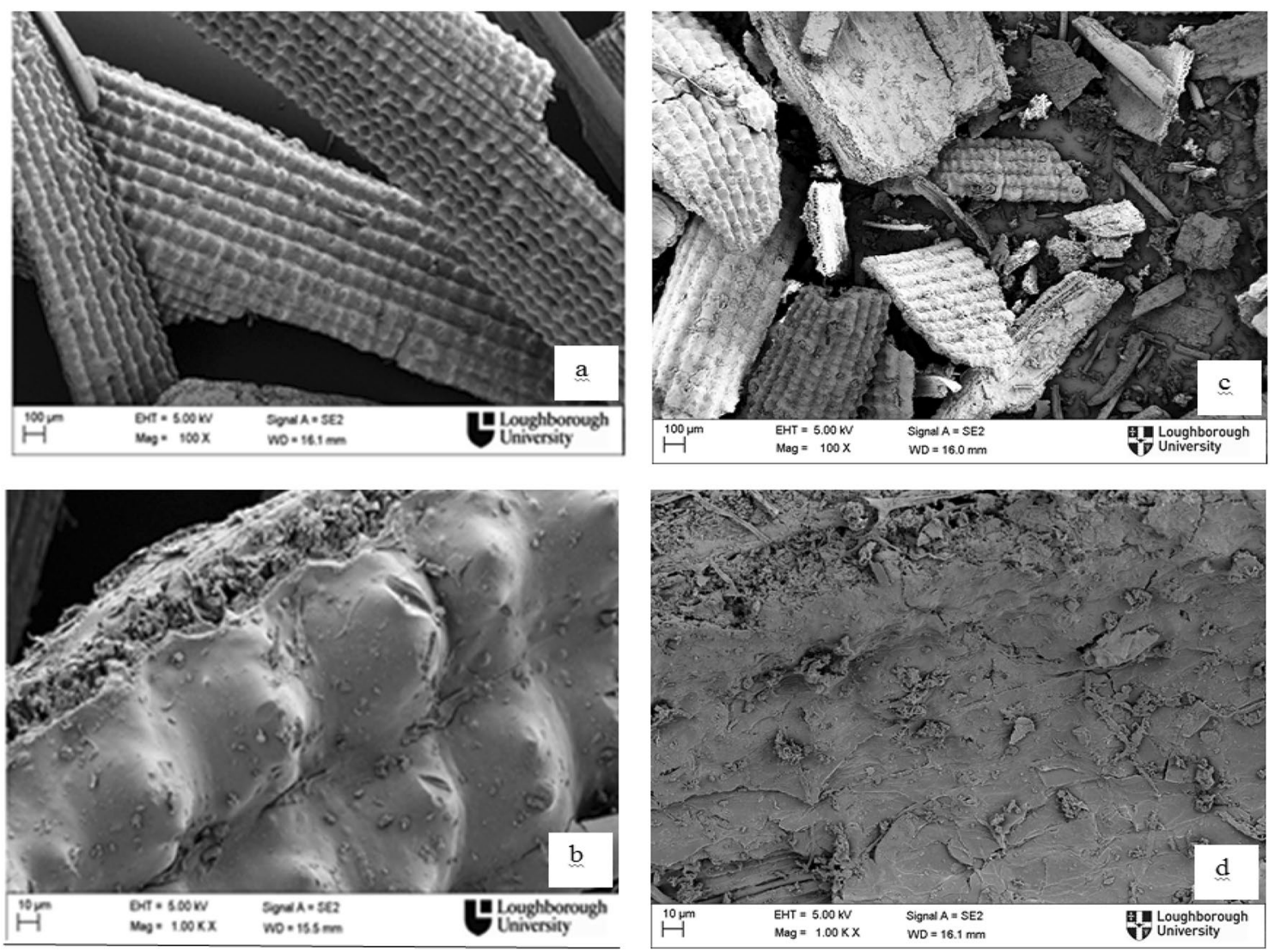

Fig. 4 SEM images of $\mathrm{RH}$ at $100 \times$ and $1000 \times$ : $\mathbf{a}$ and $\mathbf{b}$ raw rice husk; $\mathbf{c}$ and $\mathbf{d}$ hydrochar

as hydroxyl, carboxylate, and carbonyl groups, which are explained later in Sect. 3.4 from the FTIR results.

Unlike the other biomass wastes that are predominantly lignocellulolytic in composition, ES is a complex mixture of interwoven protein fibers and polysaccharides with at least $70 \%$ of the matrix being proteins [41]. In effect, the ES may not have carbonised well under the HTC conditions applied compared to the other biomasses, which was evident by the fact that the solids produced did not have a dark colour compared to the other hydrochars.

The elemental analysis by EDS revealed the presence of several elements (Table 2). Generally, carbon and oxygen were the major elements in all the samples. Like the $\mathrm{CHN}$ results, the hydrochars showed an increase in the carbon content with a corresponding decrease in the oxygen content as results of the deoxygenating and decarboxylation reactions that occurred during HTC. Calcium was largely found only in the ES, with the content increasing after carbonisation probably due to the rise in activation temperature and densification. As shown in Table 2, most of the trace elements present in the raw biomass are removed from the hydrochars following HTC. This is because most of the inorganics dissolve in the reaction media during HTC $[8,14]$.

\subsection{Surface area, pore volume and pore size characteristics}

The BET surface area and pore characteristics of the raw biomass and hydrochars are summarised in Table 3. The results showed that $\mathrm{HTC}$ at $200^{\circ} \mathrm{C}$ for $20 \mathrm{~h}$ produced hydrochars with a higher surface area and pore volume, whilst the pore size decreased compared with the corresponding raw biomass. Coconut shell hydrochar has the highest mesoporous surface area followed by the RH hydrochar, which is an indication of more active sites for adsorption of contaminants. Eggshell hydrochar has the least surface area and pore volume but the highest pore size, which was due to that fact that the ES may not have carbonised under the HTC conditions as explained earlier.

The surface areas of $\mathrm{CS}, \mathrm{CP}, \mathrm{RH}$ and $\mathrm{LP}$ hydrochars are within values reported by other studies for hydrochars from different biomass. For example, Fang et al. [17] reported that hydrochars produced from bagasse, hickory and peanut at $200{ }^{\circ} \mathrm{C}$ have higher surface area and pore volume than the starting biomass. In their study, the surface area of the hydrochars produced from bagasse, hickory and peanut were 10.70, 7.80 and $7.10 \mathrm{~m}^{2} / \mathrm{g}$ respectively. Furthermore, Titirici et al. [35] 

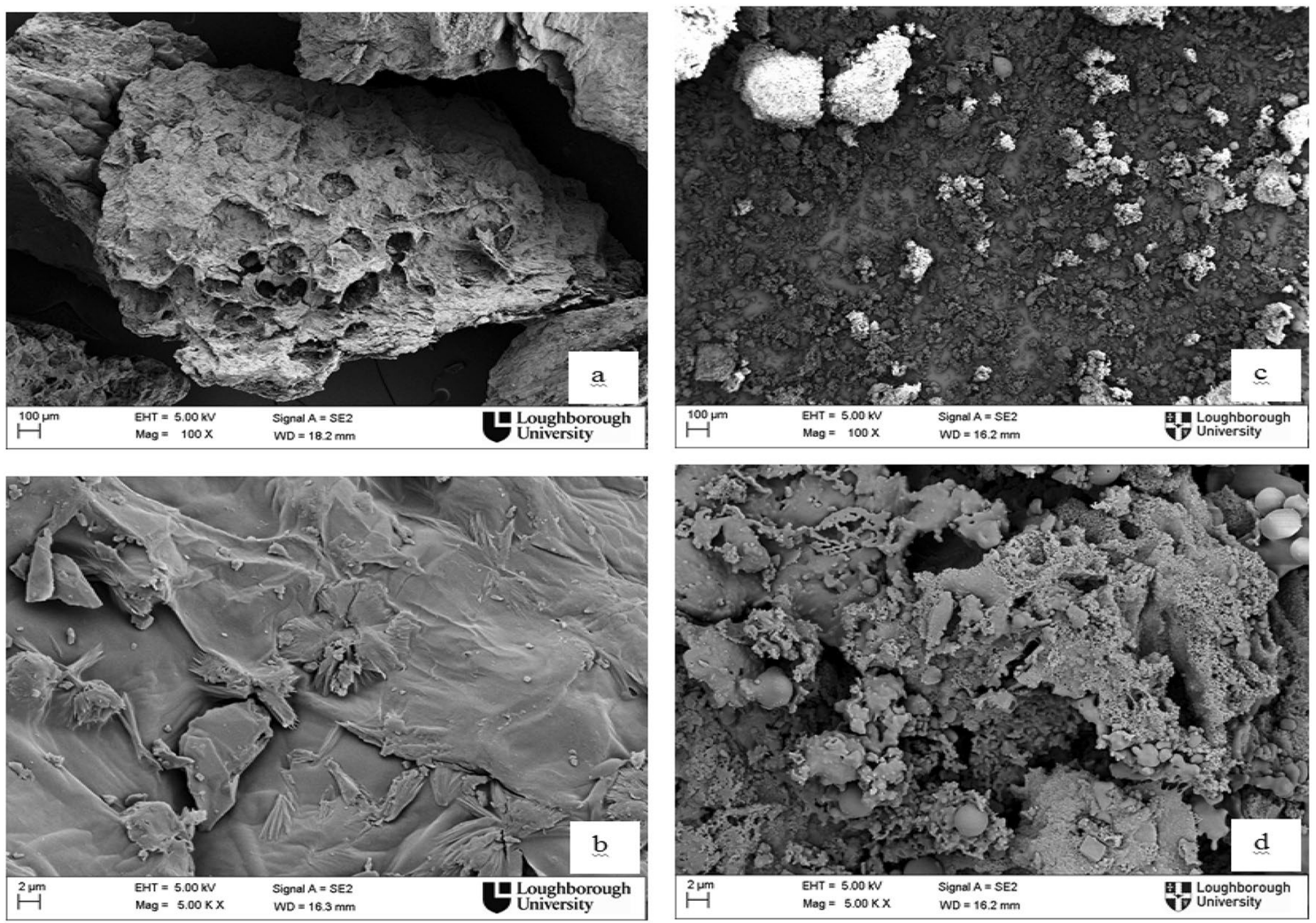

Fig. 5 SEM images of LP at 100 $\times$ and 5000x: $\mathbf{a}$ and $\mathbf{b}$ raw; $\mathbf{c}$ and $\mathbf{d}$ hydrochar

reported a meso-pore surface area (BET) of $0.20 \mathrm{~m}^{2} / \mathrm{g}$ for orange peel hydrochar carbonised at $200{ }^{\circ} \mathrm{C}$ for $20 \mathrm{~h}$, which is significantly lower than the surface area of lemon peel hydrochar obtained in this study. Other surface areas reported in their study were 12.0, 34.0 and $15.5 \mathrm{~m}^{2} / \mathrm{g}$ for pine needles, pinecone and oak leaves respectively.

The surface areas of activated carbons are higher than those found in this work as well as those reported for other hydrochars. For instance, Alaoui et al. [9] found 83.0 $\mathrm{m}^{2} / \mathrm{g}$ and $53.0 \mathrm{~m}^{2} / \mathrm{g}$ as surface areas for activated bone char pyrolysed at $400^{\circ} \mathrm{C}$ and $600^{\circ} \mathrm{C}$ respectively. Similarly, Lima and Marshall [42] reported 253.0-548.0 $\mathrm{m}^{2} / \mathrm{g}$ surface area for activated carbon produced from broiler manure pyrolysed at $700^{\circ} \mathrm{C}$ for up to $75 \mathrm{~min}$ followed by activation at $800^{\circ} \mathrm{C}$.

The characterisation by $\mathrm{N}_{2}$ adsorption-desorption plots for the adsorbents are illustrated in Fig. 7. This study revealed that higher meso-pore was obtained in the range of $1.0-4.0 \mathrm{ml} / \mathrm{g}$, indicating an onset of the porous structure with dominating pore diameter at approximately $3.0 \mathrm{ml} / \mathrm{g}$ for the hydrochars of coconut shell, rice husk and lemon peel; while the remaining hydrochars produced nonporous or macro-porous materials characterised by weak affinity between adsorbent and adsorbate and within the molecules as well. Practically, neither of these plots showed hysteresis.

The plots in Fig. 7 except that of raw rice husk correlated well with type II isotherm of the BET adsorption theory, which do not follow the Langmuir adsorption model. This means that adsorption using these materials will be monolayer (represented by the flatter region in the middle part), formation of multilayer at medium pressures and then capillary condensation at higher pressures [43]. The middle part, which is flatter represents the formation of a monolayer, which started at the knee. At medium pressures, multilayer formation occurs, and capillary condensation occurs at the higher pressures $[19,43]$. The raw rice husk plot correlated with type III isotherm, which indicates that adsorption will lead to the formation of only a multilayer. Hence, BET is not applicable because there will be no monolayer [43].

A hysteresis loop at pore size of about $5.0 \mathrm{~nm}$ for pinecone hydrochar carbonised at $200{ }^{\circ} \mathrm{C}$ for $20 \mathrm{~h}$ was reported by Titirici et al. [35]. According to their study, gas sorption measurements are sensitive only to pore sizes of up to $30.0 \mathrm{~nm}$. This means that the macro-pore structure of the hydrochars and the biomass was not indicated in these measurements. As shown in Table 3, average pore diameter of the hydrochars from the BJH method was in

\section{SN Applied Sciences}



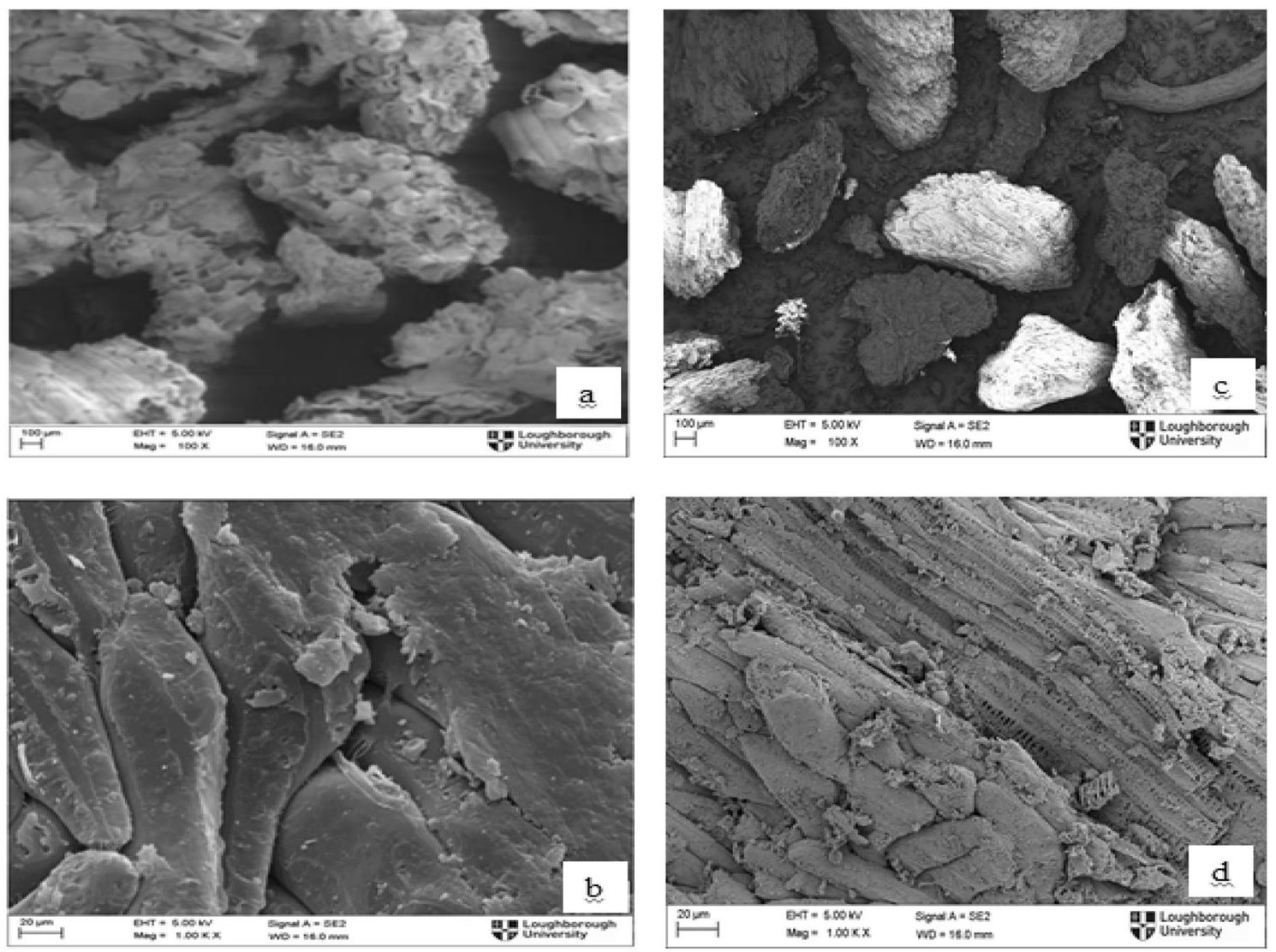

Fig. 6 SEM images of CS at 100x and 1000x: $\mathbf{a}$ and $\mathbf{b}$ raw; $\mathbf{c}$ and $\mathbf{d}$ hydrochar

Table 1 Elemental composition by $\mathrm{CHN}$ analysis

\begin{tabular}{|c|c|c|c|c|c|c|c|c|c|c|}
\hline \multirow{2}{*}{$\begin{array}{l}\text { Element } \\
\text { (\% wt.) }\end{array}$} & \multicolumn{5}{|c|}{ Raw biomass } & \multicolumn{5}{|c|}{ Hydrochar } \\
\hline & ES & $\mathrm{RH}$ & LP & $\mathrm{CP}$ & CS & ES & $\mathrm{RH}$ & LP & $\mathrm{CP}$ & CS \\
\hline C & 12.74 & 38.88 & 42.07 & 36.66 & 48.07 & 12.18 & 48.66 & 48.66 & 63.21 & 58.55 \\
\hline $\mathrm{H}$ & 0.23 & 5.39 & 5.99 & 3.95 & 5.59 & 0.20 & 4.27 & 5.63 & 4.63 & 5.40 \\
\hline $\mathrm{N}$ & 0.37 & 0.76 & 1.61 & 0.48 & 0.22 & 0.16 & 0.62 & 2.25 & 0.72 & 0.41 \\
\hline $\mathrm{O}^{\mathrm{a}}$ & 86.66 & 54.98 & 50.32 & 58.91 & 46.12 & 87.46 & 46.45 & 30.47 & 31.45 & 35.64 \\
\hline $\mathrm{H} / \mathrm{C}$ & 0.02 & 0.14 & 0.14 & 0.11 & 0.12 & 0.02 & 0.09 & 0.09 & 0.07 & 0.09 \\
\hline $\mathrm{O} / \mathrm{C}$ & 6.80 & 1.41 & 1.20 & 1.61 & 0.96 & 7.18 & 0.95 & 0.49 & 0.50 & 0.61 \\
\hline $\mathrm{C} / \mathrm{N}$ & 34.44 & 51.15 & 26.13 & 76.91 & 215.24 & 77.77 & 78.91 & 27.44 & 88.41 & 143.98 \\
\hline
\end{tabular}

${ }^{\mathrm{a}}$ Calculated as difference between 100 and total of $\mathrm{C} / \mathrm{H} / \mathrm{N}$ the range 14.02 to $18.89 \mathrm{~nm}$, with ES hydrochar having the largest pore diameter of sorption effective pores of $18.89 \mathrm{~nm}$, but the smallest absolute surface area of 0.5 $\mathrm{m}^{2} / \mathrm{g}$ for only the meso-pores. Raw rice husk has the largest pore diameter of sorption effectiveness of $40.98 \mathrm{~nm}$ and an absolute surface area of $0.46 \mathrm{~m}^{2} / \mathrm{g}$. This revealed that the hydrochars contain no micro-pores (at $<2 \mathrm{~nm}$ diameter). However, in conventional activated carbons which are produced at high temperatures; the BET method suggests presence of micro-pores $(<2 \mathrm{~nm}$ diameter) at higher surface area of over $2000 \mathrm{~m}^{2} / \mathrm{g}$ [44].

\subsection{FTIR of raw biomass and hydrochars}

\subsubsection{FTIR of coco-peat}

Figure 8(a) illustrates that strong absorptions were observed at $3333.81 \mathrm{~cm}^{-1}$ (hydroxyl stretching vibration), $2917.39 \mathrm{~cm}^{-1}$ (methylene stretching vibration), and $1029.88 \mathrm{~cm}^{-1}$ (1,4-glycosidic band), which were the characteristic bands in the cellulose structure in raw $\mathrm{CP}$. Besides, the wave number at $1606.85 \mathrm{~cm}^{-1}$ was ascribed to the skeletal $\mathrm{C}=\mathrm{C}$ stretching vibration in the aromatic 
Table 2 Elemental composition by EDS

\begin{tabular}{|c|c|c|c|c|c|c|c|c|c|c|}
\hline \multirow{2}{*}{$\begin{array}{l}\text { Element } \\
\text { (\% wt.) }\end{array}$} & \multicolumn{5}{|c|}{ Raw biomass } & \multicolumn{5}{|c|}{ Hydrochar } \\
\hline & $\overline{E S}$ & $\mathrm{RH}$ & LP & $\mathrm{CP}$ & $\mathrm{CS}$ & $\overline{\mathrm{ES}}$ & $\mathrm{RH}$ & LP & $\mathrm{CP}$ & CS \\
\hline C & 28.2 & 53.7 & 49.3 & 54.6 & 62.2 & 28.6 & 71.4 & 72.5 & 67.8 & 85.9 \\
\hline $\mathrm{O}$ & 39.4 & 43.8 & 48.4 & 41.2 & 35.5 & 29.9 & 28.4 & 26.0 & 31.5 & 13.9 \\
\hline $\mathrm{Ca}$ & 26.3 & 0.7 & 0.5 & 0.2 & - & 36.1 & - & 1.0 & 0.1 & - \\
\hline$P$ & 3.5 & - & - & - & - & 4.4 & - & - & - & - \\
\hline S & 0.4 & - & - & - & - & 0.3 & - & - & - & 0.1 \\
\hline $\mathrm{Si}$ & - & 1.1 & - & 0.2 & - & - & - & - & 0.2 & - \\
\hline $\mathrm{Cl}$ & - & 0.2 & - & 0.9 & - & - & - & - & - & - \\
\hline K & 0.1 & 0.2 & 1.0 & 1.6 & 0.1 & - & - & - & - & - \\
\hline $\mathrm{Na}$ & - & - & 0.1 & 0.4 & 0.1 & - & - & 0.1 & - & - \\
\hline $\mathrm{Mg}$ & 1.1 & - & 0.1 & 0.1 & - & 0.7 & - & 0.1 & - & 0.8 \\
\hline $\mathrm{Pb}$ & 0.2 & - & 0.2 & 0.2 & - & - & - & - & - & 0.5 \\
\hline $\mathrm{Fe}$ & 0.1 & 0.1 & 0.1 & 0.1 & 0.1 & - & 0.1 & 0.1 & 0.2 & - \\
\hline $\mathrm{Al}$ & 0.1 & - & 0.1 & 0.1 & - & - & 0.1 & - & 0.1 & - \\
\hline $\mathrm{Mn}$ & - & 0.1 & - & - & - & - & - & - & - & - \\
\hline $\mathrm{Cu}$ & - & 0.1 & 0.1 & 0.2 & 0.1 & - & 0.1 & 0.2 & 0.1 & - \\
\hline
\end{tabular}

rings' bands of lignin. Also, the appearance of an absorption band at $1420.68 \mathrm{~cm}^{-1}$ was related to the stretching vibration of $\mathrm{C}-\mathrm{O}-\mathrm{C}$ group ring vibrations of carbohydrates. The strong band at $1424.22 \mathrm{~cm}^{-1}$ was a characteristic of a weak vibration of the aliphatic $\mathrm{N}-\mathrm{O}$ group. The stretched absorption peak at $512.87 \mathrm{~cm}^{-1}$ could be assigned to the presence of alkyl halide ( $\mathrm{C}-\mathrm{X})$ and disulphide groups. Peak $1235.42 \mathrm{~cm}^{-1}$ corresponds to $C-O$, which indicates the presence of carboxylic acid groups. However, Fig. 8(b) is the hydrochar of CP which shows a slight shift in the absorptions observed at 3341.97 and $2937.81 \mathrm{~cm}^{-1}$ compared to the raw CP. Carbonisation leads to dehydration and deoxygenation of the material forming more carbon

Table 3 Surface characteristics of the various biomass adsorbents

\begin{tabular}{|c|c|c|c|}
\hline \multirow[t]{2}{*}{ Materials } & \multicolumn{3}{|l|}{ Parameters } \\
\hline & $\begin{array}{l}\text { BET surface } \\
\text { area }\left(\mathrm{m}^{2} / \mathrm{g}\right)\end{array}$ & $\begin{array}{l}\text { Pore volume } \\
\left(\mathrm{cm}^{3} / \mathrm{g}\right)\end{array}$ & $\begin{array}{l}\text { BJH pore size } \\
(\mathrm{nm})\end{array}$ \\
\hline \multicolumn{4}{|l|}{ Raw biomass } \\
\hline Coconut shell & 0.710 & 0.003 & 17.860 \\
\hline Coco-peat & 1.230 & 0.004 & 21.460 \\
\hline Rice husk & 0.460 & 0.003 & 40.980 \\
\hline Lemon peel & 0.310 & 0.001 & 20.070 \\
\hline Egg shell & 0.090 & 0.001 & 21.160 \\
\hline \multicolumn{4}{|l|}{ Hydrochar } \\
\hline Coconut shell & 21.820 & 0.090 & 14.020 \\
\hline Coco-peat & 2.140 & ND & 8.850 \\
\hline Rice husk & 15.740 & 0.031 & 8.850 \\
\hline Lemon peel & 6.890 & 0.037 & 13.630 \\
\hline Egg shell & 0.500 & 0.002 & 18.890 \\
\hline
\end{tabular}

$\mathrm{ND}=$ Below detection level due to fewer than 2 data points content [14]. This could be the reason for the shift in the observed absorption.

\subsubsection{FTIR of coconut shell}

FTIR spectrum of the raw CS and hydrochar after carbonisation are shown in Fig. 9. From the result of the raw CS (Fig. 9a), the band shifting around the broad peak at $3343.69 \mathrm{~cm}^{-1}$ indicates the possible involvement of a hydroxyl group. The peak at $2929.98 \mathrm{~cm}^{-1}$ is due to the $\mathrm{CH}$ stretching that causes vibrations of $\mathrm{CH}, \mathrm{CH}_{2}$ and $\mathrm{CH}_{3}$ groups. The major changes that are seen in the regions from $3343.69 \mathrm{~cm}^{-1}$ and $2929.28 \mathrm{~cm}^{-1}$ to $3336.98 \mathrm{~cm}^{-1}$ and $2938.45 \mathrm{~cm}^{-1}$ are due to the presence of hydroxyl group $(\mathrm{OH})$ and alkyl $(\mathrm{CH})$ stretching, which is greatly decreased. However, by charring, lignin in the raw CS was decomposed via deoxygenating and dehydration resulting in a hydrochar with high carbon content.

The intensity spectrum of CS hydrochar is shown in Fig. 9(b), which was lower compared to its raw CS. The low intensity is an indication that $\mathrm{C}-\mathrm{H}$ has peaks below $950 \mathrm{~cm}^{-1}$. This observation is consistent with the results obtained from the previous elemental analysis.

\subsubsection{FTIR of rice husk}

The FTIR spectra of raw RH (Fig. 10 a) shows some dominant peaks at $3333.93 \mathrm{~cm}^{-1}, 2917.65 \mathrm{~cm}^{-1}, 1634.66 \mathrm{~cm}^{-1}$, $1032.83 \mathrm{~cm}^{-1}$, and $783.68 \mathrm{~cm}^{-1}$, which represent $\mathrm{O}-\mathrm{H}$ stretching, aliphatic $\mathrm{C}-\mathrm{H}$ stretching, aldehyde $\mathrm{C}-\mathrm{H}$ stretching, $\mathrm{C}-\mathrm{O}-\mathrm{H}$ stretching, and $\mathrm{Si}-\mathrm{O}$ stretching, respectively. These peaks changed with the carbonised rice husk where the $\mathrm{O}-\mathrm{H}$ stretches at $3398.71 \mathrm{~cm}^{-1}$, 

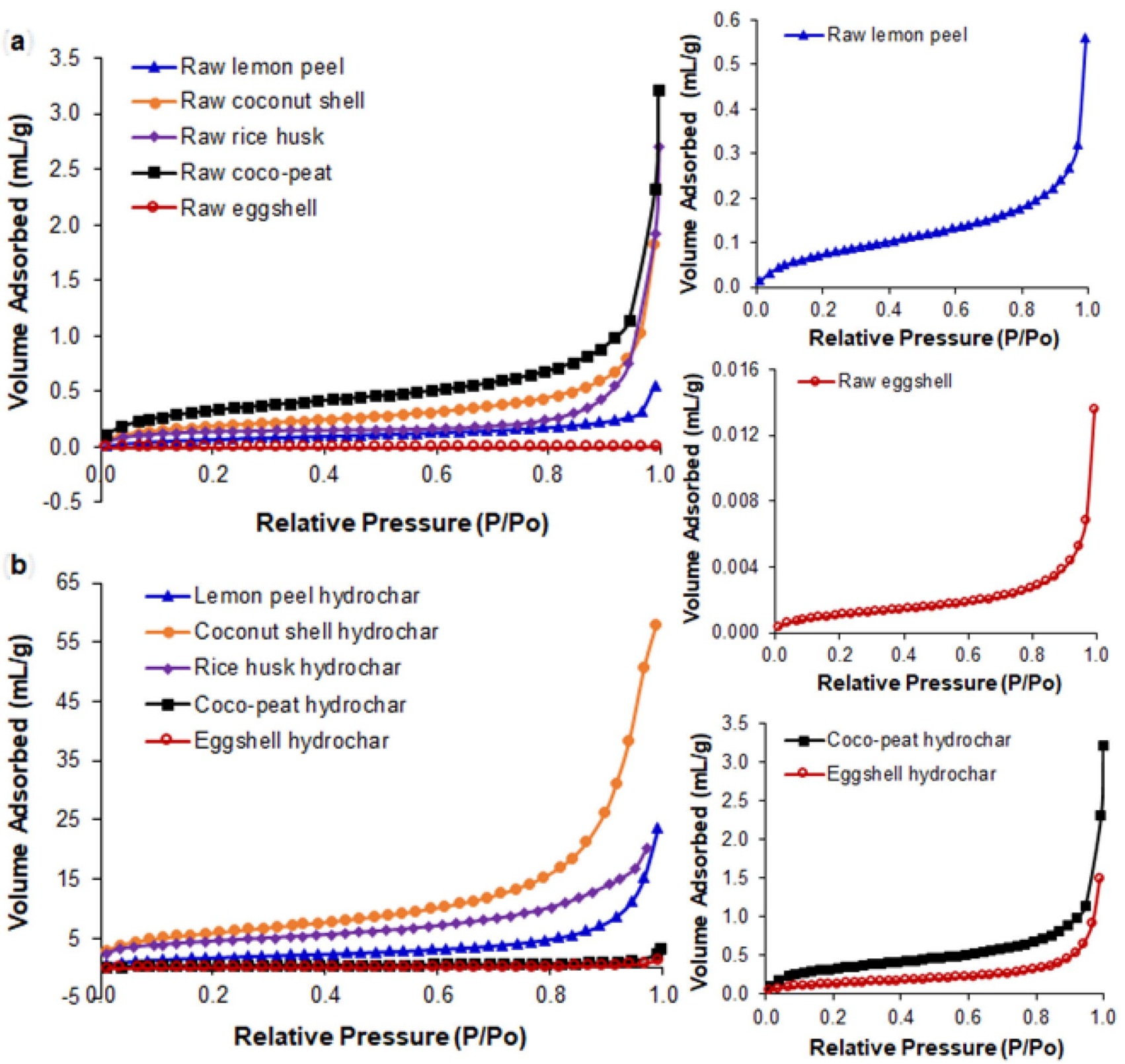

Fig. 7 Gas sorption measurements characterising the meso-pore structure of the: a raw biomass; and $\mathbf{b}$ hydrochars

aliphatic $\mathrm{C}-\mathrm{H}$ stretching at $1616.90 \mathrm{~cm}^{-1}$ and the $\mathrm{C}-\mathrm{O}-\mathrm{H}$ stretching at $1030.54 \mathrm{~cm}^{-1}$ reduced greatly, but the $\mathrm{Si}-\mathrm{O}$ stretching at $788.07 \mathrm{~cm}^{-1}$ can be observed as shown in Fig. 10 (b). From a physical perspective, there was no significant variation between the band peaks in the hydrochar to those observed in the raw biomass. This means that even after carbonisation, fragments of lignin and other intermediate structures remained; indicating their inability to be totally decomposed during deoxygenation and dehydration reactions at the HTC temperature.

\subsubsection{FTIR of lemon peel}

The FTIR spectra of raw LP (Fig. 11a) shows a peak at $3289.52 \mathrm{~cm}^{-1}$, which represents $\mathrm{O}-\mathrm{H}$ groups in the carbohydrate and lignin. The intense peak around $1017.46 \mathrm{~cm}^{-1}$ corresponds to the linkage of $\mathrm{C}-\mathrm{O}-\mathrm{H}$ or $\mathrm{C}-\mathrm{O}-\mathrm{R}$ (alcohols or esters), while the $\mathrm{C}-\mathrm{H}$ stretching is represented in the peak around $2919.26 \mathrm{~cm}^{-1}$ and $2851.35 \mathrm{~cm}^{-1}$. Carbonisation of the lemon peel reduced these peaks Fig. 11(b), but still there were observations 

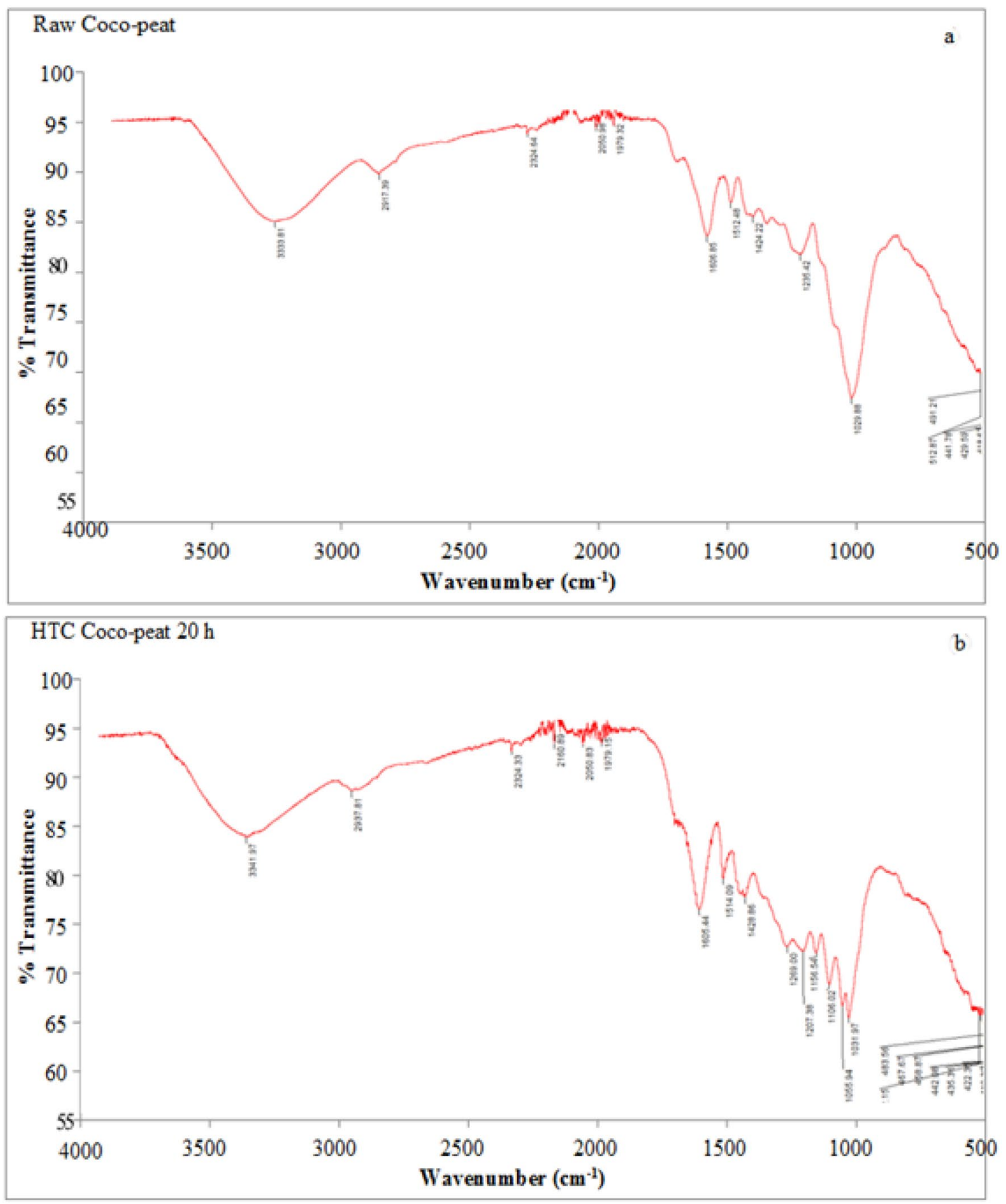

Fig. 8 Characteristics bands of functional groups in: $\mathbf{a}$ raw CP; $\mathbf{b}$ CP hydrochar

of the $\mathrm{O}-\mathrm{H}$ group and $\mathrm{C}-\mathrm{H}$ stretching with slight intensity for the linkage of $\mathrm{C}-\mathrm{O}-\mathrm{H}$ or $\mathrm{C}-\mathrm{O}-\mathrm{R}$ (alcohols or esters). These functional groups are characterised by the presence of protein, pectin, cellulose and pigments.

\subsubsection{FTIR of eggshell}

The observation described in Sect. 3.2 about the EDS on eggshell was also demonstrated by the FTIR spectra, 

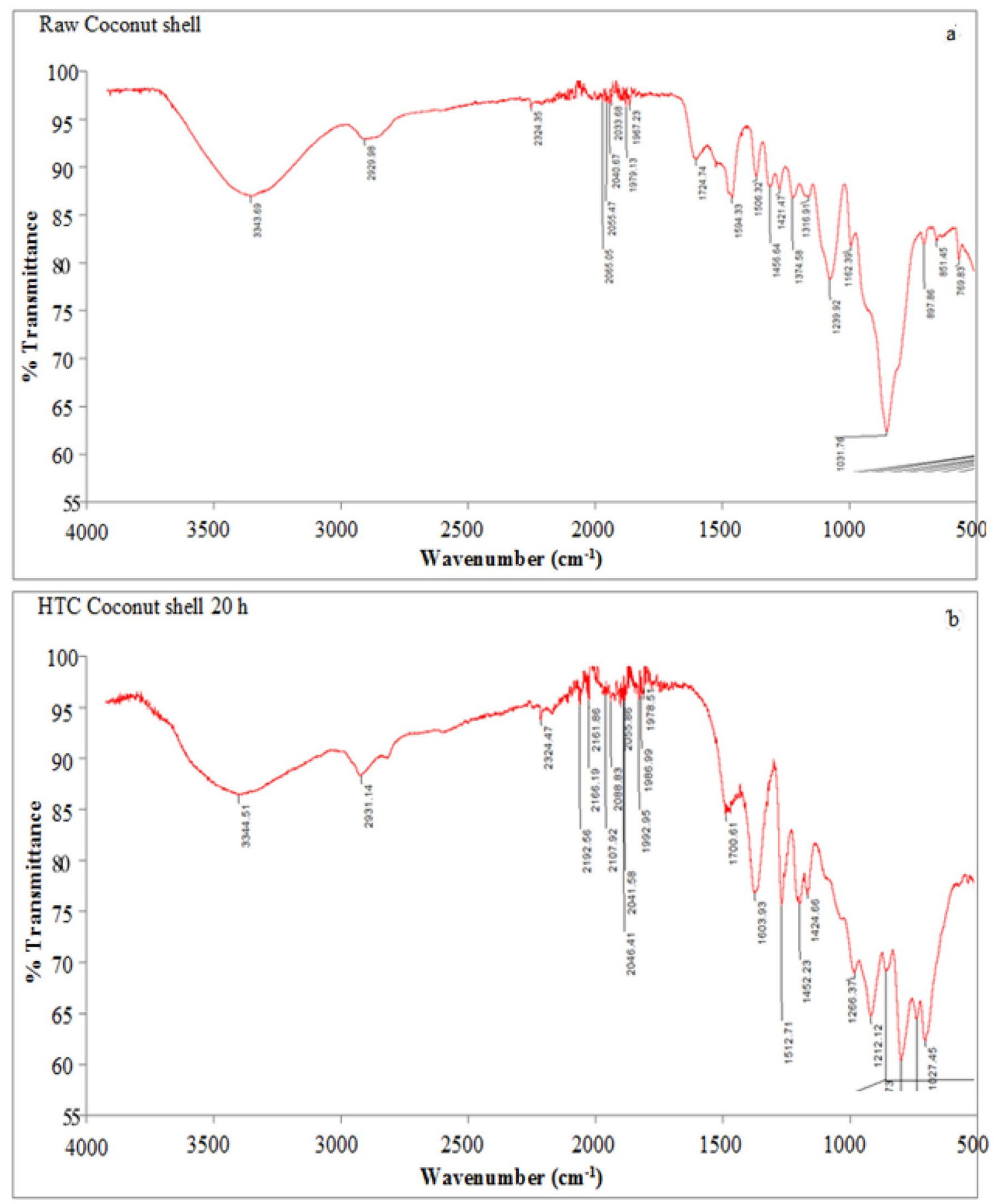

Fig. 9 Characteristics bands of functional groups in: a raw CS; and $\mathbf{b}$ CS hydrochar

shown in Fig. 12(a). The intensity of the peaks for the raw ES were significant at $1393.63,871.16$ and $711.98 \mathrm{~cm}^{-1}$, which is strongly associated with the presence of carbonate minerals alkyl halide within the ES matrix. In Fig. 12(a), the two notable peaks $3278.58 \mathrm{~cm}^{-1}$ and $1645.37 \mathrm{~cm}^{-1}$ associated with $-\mathrm{OH}$ and $\mathrm{C}-\mathrm{H}$ group are missing in the hydrochar as shown in Fig. 12(b). This may be due to the in-plane and out-plane deformation modes of the calcium carbonate during carbonisation. Hence, it can be deduced that carbonisation via $\mathrm{HTC}$ at $200^{\circ} \mathrm{C}$ for $20 \mathrm{~h}$ did not have a significant change on the surface functionality.

\subsubsection{Summary of the functional groups}

Table 4 summarises the intensity of peaks on the IR (infrared) absorption spectra and their interpretations. The raw 

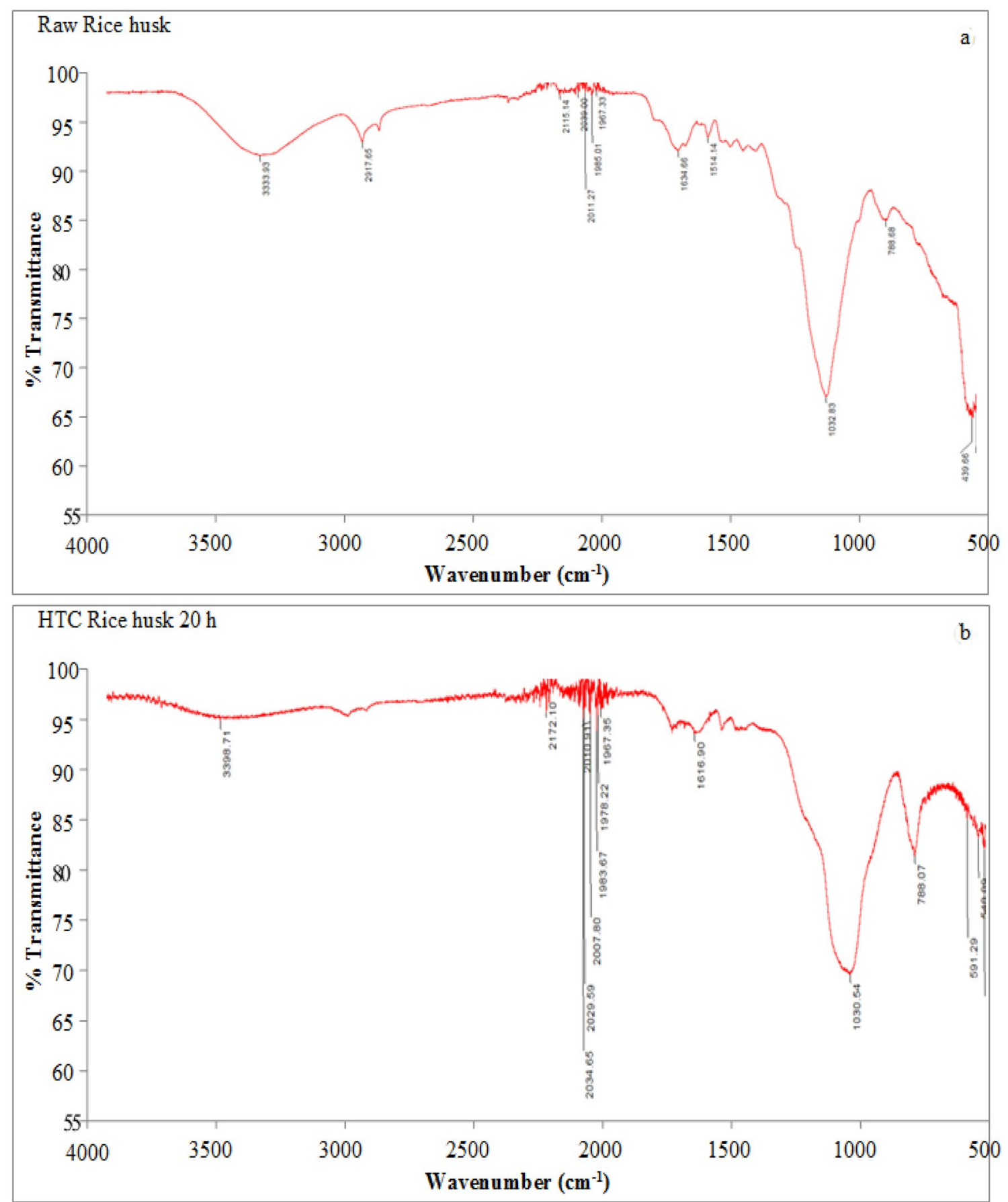

Fig. 10 Characteristics bands of functional groups in: a raw $\mathrm{RH}$; and $\mathbf{b} \mathrm{RH}$ hydrochar

biomass has shown to contain constituents such as glucose, lignocellulosic, cellulose, hemicelluloses and lignin. However, some constituents observed in raw biomass disappeared in the corresponding hydrochar.

The hydrochars contain a larger number of oxygenated functional groups, such as hydroxyl, carboxylate, aromatic and carbonyl groups than their corresponding raw biomass. These functional groups have been found to yield a greater cation exchange capacity (CEC), which is beneficial for sorption of positively charged contaminants such as heavy metals $[15,17,18,45]$. This indicates that the hydrochars produced in this study have the potential for used as sorbents for heavy metals and other contaminants. 

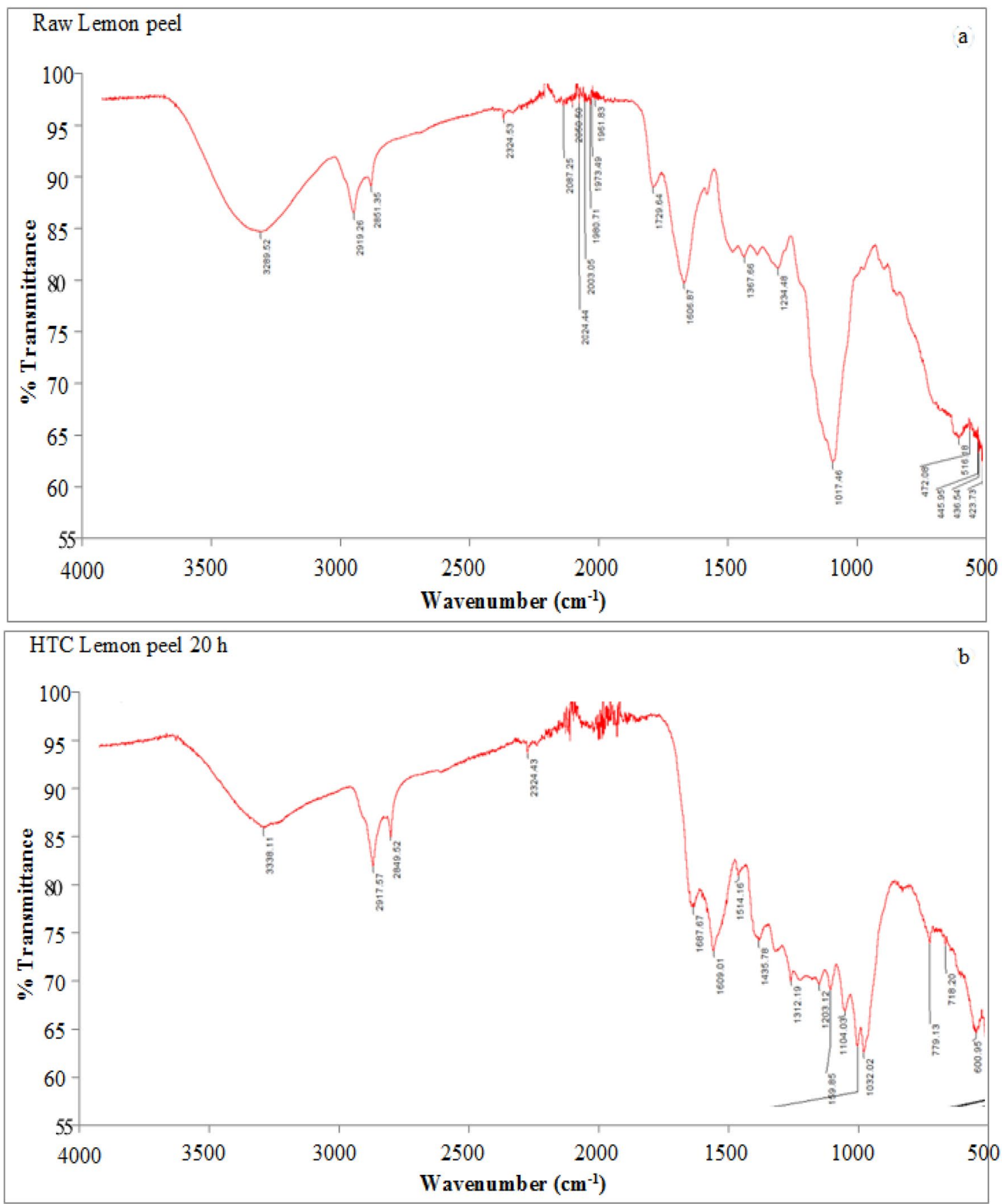

Fig. 11 Characteristics bands of functional groups in: $\mathbf{a}$ raw LP; and $\mathbf{b}$ LP hydrochar

\section{Conclusion}

Biomass wastes comprising of coco-peat (CP), coconut shell (CS), rice husk (RH), lemon peel (LP) and eggshell (ES) were hydrothermally treated at $200^{\circ} \mathrm{C}$ for $20 \mathrm{~h}$ in order to investigate their potential to be used as adsorbents and to examine the effect of the carbonisation on their sorption characteristics. The study demonstrated that the hydrochars produced from these biomass wastes have the potential to be used as adsorbents. Except for raw rice husk that exhibited type III isotherm, all the raw biomass and the hydrochars correlated well with type II isotherm. The SEM images showed that the hydrochars have porous structures, which resulted from denaturing of biomass structures. The surface area of the hydrochars were significantly higher than the 


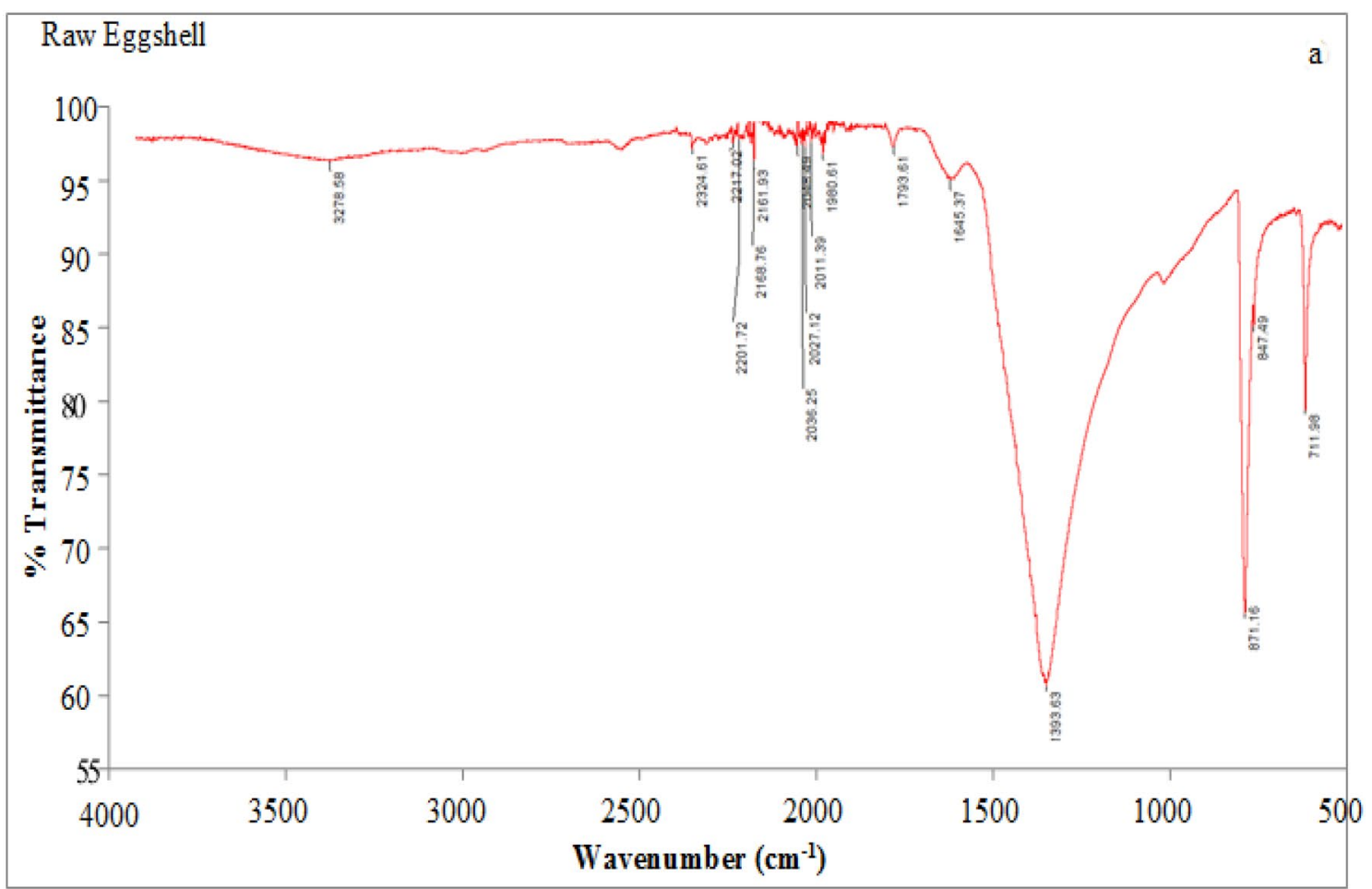

HTC Eggshell $20 \mathrm{~h}$

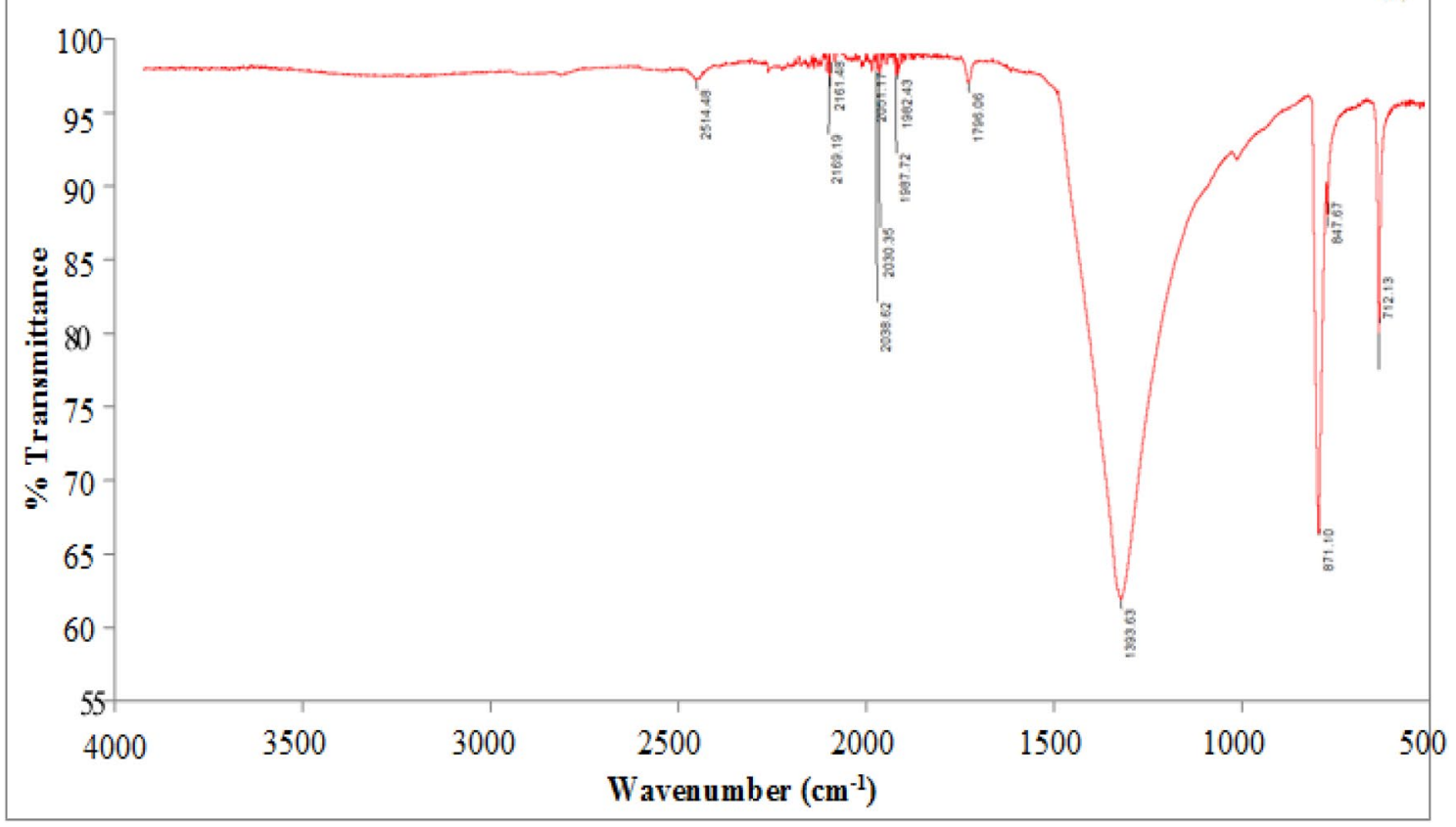

Fig. 12 Characteristic bands of functional groups in: a raw ES; and $\mathbf{b}$ ES hydrochar

corresponding raw biomass, with CS hydrochar having the largest surface area $\left(21.82 \mathrm{~m}^{2} / \mathrm{g}\right)$, whilst ES hydrochar the smallest $\left(0.5 \mathrm{~m}^{2} / \mathrm{g}\right)$. The enhanced porosity and surface area of the hydrochars result in more characteristics active sites for sorption of pollutants. The hydrochars have an increase in the carbon content and a decrease in oxygen content with lower $\mathrm{H} / \mathrm{C}$ and $\mathrm{O} / \mathrm{C}$ ratios than the untreated biomass, which indicate that the hydrochars have high levels of aromaticity and greater abundances of oxygenated surface functional groups. The major functional groups identified in the hydrochars were the hydroxyl $(-\mathrm{OH})$ and carboxylic acids $(-\mathrm{COOH})$, 
Table 4 Summary of IR absorptions in raw biomass and hydrochars

\begin{tabular}{|c|c|c|c|c|}
\hline \multirow[t]{2}{*}{ Adsorbent } & \multicolumn{2}{|c|}{ Wavelength $\left(\mathrm{cm}^{-1}\right)$} & \multirow[t]{2}{*}{ Functional group } & \multirow[t]{2}{*}{ Interpretation } \\
\hline & Raw biomass & Hydrochar & & \\
\hline \multirow[t]{5}{*}{ Coco-peat } & 3333.81 & 3341.97 & $\mathrm{O}-\mathrm{H}$ & $\begin{array}{l}\text { Indicates the presence of hydroxyl, water, alcohols due to cellulose, phenols } \\
\text { and lignin }\end{array}$ \\
\hline & 2917.39 & 2937.81 & $\mathrm{C}-\mathrm{H}$ & Indicates the presence of alkane suggesting methyl and methylene groups \\
\hline & 1606.85 & 1605.44 & $\mathrm{C}=\mathrm{C}$ & Presence of aromatic rings due to lignin \\
\hline & 1235.45 & 1031.97 & $\mathrm{C}-\mathrm{O}$ & Due to vibration from ethers, phenols, aliphatic alcohols \\
\hline & 512.87 & - & $\mathrm{C}-\mathrm{Br}$ & Alkyl halide \\
\hline \multirow[t]{5}{*}{ Coconut shell } & 3343.69 & 3344.51 & $\mathrm{O}-\mathrm{H}$ & Presence of hydroxyl, water, alcohols due to cellulose, phenols and lignin \\
\hline & 2929.98 & 2931.14 & $\mathrm{C}-\mathrm{H}$ & $\begin{array}{l}\text { Small peaks due to absorption from } \mathrm{CH} \text { bond of aliphatic carbon, methylene, } \\
\text { and methyl groups }\end{array}$ \\
\hline & 1724.74 & 1603.93 & $\mathrm{C}=\mathrm{O}$ & $\begin{array}{l}\text { The vibration due to the esters, carboxylic acids or aldehydes or ketone pre- } \\
\text { sent in the cellulose and lignin }\end{array}$ \\
\hline & 1239.92 & 1027.45 & $\mathrm{C}-\mathrm{O}$ & Presence of ethers, phenols, aliphatic alcohols \\
\hline & 1031.76 & - & $\mathrm{C}-\mathrm{O}-\mathrm{H}$ & Means there is deformation in cellulous \\
\hline \multirow[t]{5}{*}{ Rice husk } & 3333.93 & 3398.71 & $\mathrm{~N}-\mathrm{H}$ & $\begin{array}{l}\text { Occurrence of } \mathrm{OH} \text {, carboxyl and amine groups due to high formation of } \\
\text { amide in the hydrochar }\end{array}$ \\
\hline & 2917.65 & - & $\mathrm{C}-\mathrm{H}$ & $\begin{array}{l}\text { Small peaks due to absorption from } \mathrm{CH} \text { bond of aliphatic carbon, methylene, } \\
\text { and methyl groups }\end{array}$ \\
\hline & 1634.66 & 1616.90 & $\mathrm{C}=\mathrm{O}$ & Aliphatic $\mathrm{C}-\mathrm{H}$ stretching \\
\hline & 1032.83 & 1030.54 & $\mathrm{C}-\mathrm{O}-\mathrm{H}$ & Means there is deformation in cellulose \\
\hline & 783.68 & 788.07 & $\mathrm{Si}-\mathrm{O}$ & Indicates the vibration of silica \\
\hline \multirow[t]{4}{*}{ Lemon peel } & 3289.52 & 3338.11 & $\mathrm{O}-\mathrm{H}$ & $\begin{array}{l}\text { Hydroxyl, carbohydrate and lignin. Indicates the presence of constituents } \\
\text { such as protein, pectin and cellulose }\end{array}$ \\
\hline & 2919.26 & 2917.57 & $\mathrm{C}-\mathrm{O}-\mathrm{R}$ & Presence of esters \\
\hline & 1606.87 & 1609.01 & $\mathrm{C}=\mathrm{O}$ & Aromatic skeletal vibration \\
\hline & - & 600.95 & $\mathrm{C}-\mathrm{Cl}$ & Alkyl halide \\
\hline \multirow[t]{5}{*}{ Eggshell } & 3278.58 & - & $\mathrm{OH}$ & $\begin{array}{l}\text { Hydroxyl, carbohydrate, and lignin. Indicates the presence of constituents } \\
\text { such as protein, pectin, and cellulose }\end{array}$ \\
\hline & 1793.61 & 1796.06 & $\mathrm{C}=\mathrm{O}$ & $\begin{array}{l}\text { The vibration due to the presence of esters, carboxylic acids or aldehydes and } \\
\text { ketone }\end{array}$ \\
\hline & 1393.63 & 1393.63 & $\mathrm{CH}_{3}$ bend & Aliphatic $\mathrm{C}-\mathrm{H}$ stretch in $\mathrm{CH}_{3}$ \\
\hline & 871.16 & 871.10 & $\mathrm{C}-\mathrm{F}$ & Presence of aromatic ring \\
\hline & 711.98 & 712.13 & $\mathrm{C}-\mathrm{Br}$ & Presence of aromatic ring \\
\hline
\end{tabular}

which indicate that the hydrochars have the potential to be used for inorganic and organic contaminants remediation purposes. Conclusively, the abundance of these biomass waste materials in developing countries and the moderate HTC temperature required make these produced hydrochars suitable for potential practical applications, especially in developing countries.

Acknowledgements The authors would like to extend their thanks to Jayshree Bhuptani and Geoffrey Russell, School of Architecture, Building and Civil Engineering for providing the enabling environment to carry out some aspects of this study; Dr. Keith Yendall and Monika Pietrzak, School of Chemical and Materials Engineering, who assisted with SEM/EDS and surface area analyses by BET respectively. Special thanks to Dr. Kevin Bass, Centre for Renewable Energy Systems Technology who allowed us to use FTIR facility and Alastair Daley in Chemistry Department who helped with CHN elemental analysis.
Funding This research was supported by the Petroleum Technology Development Fund (PTDF), Abuja, Nigeria.

\section{Compliance with ethical standards}

Conflict of interests The authors declare that they have no conflict of interests.

Open Access This article is licensed under a Creative Commons Attribution 4.0 International License, which permits use, sharing, adaptation, distribution and reproduction in any medium or format, as long as you give appropriate credit to the original author(s) and the source, provide a link to the Creative Commons licence, and indicate if changes were made. The images or other third party material in this article are included in the article's Creative Commons licence, unless indicated otherwise in a credit line to the material. If material is not included in the article's Creative Commons licence and your intended use is not permitted by statutory regulation or exceeds the permitted 
use, you will need to obtain permission directly from the copyright holder. To view a copy of this licence, visit http://creativecommons .org/licenses/by/4.0/.

\section{References}

1. Amarasinghe BMWPK, Williams RA (2007) Tea waste as a low cost adsorbent for the removal of $\mathrm{Cu}$ and $\mathrm{Pb}$ from wastewater. Chem Eng J 132(1-3):299-309

2. Acheampong MA, Ansa EDO, Woode MY, Awuah E (2015) Biosorption of $\mathrm{Pb}$ (II) onto Cocos nucifera shell and Moringa oleifera seeds. J Chem Eng Commun 6445(202):946-953

3. Mihajlović M, Petrović J, Stojanović M et al (2016) Hydrochars, perspective adsorbents of heavy metals: a review of the current state of studies. Zastita Materijala 57:488-495

4. Annadural G, Juang RS, Lee DJ (2003) Adsorption of heavy metals from water using banana and orange peels. Water Sci Technol 47(1):185-190

5. Saka C, Şahin Ö, Küçük MM (2012) Applications on agricultural and forest waste adsorbents for the removal of lead(II) from contaminated waters. Int J Environ Sci Technol 9(2):379-394

6. Ozacar M (2003) Adsorption of phosphate from aqueous solution onto alunite. Chemosphere 51:321-327

7. Liu Z, Zhang FS (2009) Removal of lead from water using biochars prepared from hydrothermal liquefaction of biomass. $J$ Hazard Mater 167:933-939

8. Libra JA, Ro KS, Kammann C et al (2011) Hydrothermal carbonization of biomass residuals: a comparative review of the chemistry, processes and applications of wet and dry pyrolysis. Biofuels 2(1):89-124

9. Alaoui NS, Laghdach AE, Correa EM, Stitou M, Yousfi FE, Jbari N (2014) Preparation of bone chars by calcination in traditional furnace. J Mater Environ Sci 5(2):476-483

10. Silva MP, Lobos MLN, Piloni RV et al (2020) Pyrolytic biochars from sunflower seed shells, peanut shells and Spirulina algae: their potential as soil amendment and natural growth regulators. SN Appl Sci 2:1926. https://doi.org/10.1007/s42452-02003730-X

11. Gumus RH (2016) Kinetic studies of methylene blue adsorption on to activated carbon prepared from plantain pod (Musa paradisiac). Br J Appl Sci Technol 15(3):1-14

12. Lima IM, McAloon A, Boateng AA (2008) Activated carbon from broiler litter: process description and cost of production. Biomass Bioenergy 32(6):568-572

13. Funke A, Ziegler F (2010) Hydrothermal carbonization of biomass: a summary and discussion of chemical mechanisms for process engineering. Biofuel Bioprod Biorefining 4:160-177

14. Danso-Boateng E, Shama G, Wheatley AD, Martin SJ, Holdich RG (2015) Hydrothermal carbonisation of sewage sludge: effect of process conditions on product characteristics and methane production. Bioresour Technol 177:318-327

15. Fuertes $A B$, Arbestain $M$, Sevilla $M$ et al (2010) Chemical and structural properties of carbonaceous products obtained by pyrolysis and hydrothermal carbonisation of corn stover. Aust J Soil Res 48:618-626

16. Parshetti GK, Hoekman SK, Balasubramanian R (2013) Chemical, structural and combustion characteristics of carbonaceous products obtained by hydrothermal carbonization of palm empty fruit bunches. Bioresour Technol 135:683-689

17. Fang J, Gao B, Chen J, Zimmerman AR (2015) Hydrochars derived from plant biomass under various conditions: characterization and potential applications and impacts. Chem Eng J 267:253-259

\section{SN Applied Sciences

18. Kumar S, Loganathan VA, Gupta RB, Barnett MO (2011) An assessment of $\mathrm{U}(\mathrm{VI})$ removal from groundwater using biochar produced from hydrothermal carbonization. J Environ Manag 92(10):2504-2512. https://doi.org/10.1016/j.jenvm an.2011.05.013

19. Danso-Boateng E, Eleni Nyktari E, Wheatley DA, Holdich GR, Mohammed SA (2020) Removal of organic pollutants from effluent of anaerobic digester using hydrochars produced from faecal simulant and sewage sludge. Water Air Soil Pollut 231:192. https://doi.org/10.1007/s11270-020-04557-3

20. Regmi P, Moscoso J, Kumar S, Cao X, Mao J, Schafran G (2012) Removal of copper and cadmium from aqueous solution using switchgrass biochar produced via hydrothermal carbonization process. J Environ Manag 109:61-69

21. Robbins R (2013) Scanning electron microscope operation zeiss supra-40. The University of Texas at Dallas, Erik Jonsson School of Engineering

22. ASTM (2008) Standard test methods for instrumental determination of carbon, hydrogen, and nitrogen in laboratory samples of coal. ASTM-D5373-08. ASTM International, Pennsylvania

23. Pilon G, Lavoie J (2014) Biomass char production at low severity conditions under $\mathrm{CO}_{2}$ and $\mathrm{N}_{2}$ environments. Biomass Biofuels, WIT Trans State Art Sci Eng 83:67-78. https://doi. org/10.2495/978-1-78466-034-5/007

24. Barrett EP, Joyner LG, Halenda PP (1951) The determination of pore volume and area distributions in porous substances. I. Computations from nitrogen isotherms. J Am Chem Soc 1896(1948):373-380

25. Hunton $P$ (2005) Research on eggshell structure and quality: an historical overview. Braz J Poult Sci 7(2):67-71

26. Zaman T, Mostari MS, Mahmood MA, Rahman MS (2018) Evolution and characterization of eggshell as a potential candidatsse of raw material. Cerâmica 64(370):236-241

27. Vijayaraghavan K, Jegan J, Palanivelu K, Velan M (2005) Removal and recovery of copper from aqueous solution by eggshell in a packed column. Miner Eng 18(5):545-547

28. Rencoret J, Ralph J, Marques G, Gutiérrez A, Martínez ÁT, del Río JC (2013) Structural characterization of lignin isolated from coconut (Cocos nucifera) coir fibers. J Agric Food Chem 61:24342445. https://doi.org/10.1021/jf304686x

29. Ji-lu Z (2007) Bio-oil from fast pyrolysis of rice husk: Yields and related properties and improvement of the pyrolysis system. J Anal Appl Pyrol 80:30-35

30. Kunal B, Bahurudeen A, Mohammed-Haneefa K, Mahalingam B (2015) Microstructural characterization of rice husk and residual ash for the production of superior blended concrete. Int J Res Eng Technol 4(13):327-332

31. Qiang L, Xu-lai Y, Xi-Feng Z (2008) Analytical and applied pyrolysis analysis on chemical and physical properties of bio-oil pyrolyzed from rice husk. J Anal Appl Pyrol 82:191-198

32. Kamsonlian S, Suresh S, Majumder CB, Chand S (2011) Characterization of banana and orange peels: biosorption mechanism. Int J Sci Technol Manag 2(4):1-7

33. Liyanage CD, Pieris M (2015) A physico-chemical analysis of coconut shell powder. Proc Chem 16:222-228

34. Pino GH, Souza De-Mesquita LM, Torem ML, Saavedra Pinto GA (2006) Biosorption of cadmium by green coconut shell powder. Miner Eng 19:380-387

35. Titirici MM, Thomas A, Yu SH, Muller JO, Antonietti M (2007) A direct synthesis of mesoporous carbons with bicontinuous pore morphology from crude plant material by hydrothermal carbonization. J Chem Mater 9(17):4205-4212

36. Heilmann SM, Davis HT, Jader LR et al (2010) Hydrothermal carbonisation of microalgae. Biomass Bioenergy 34(6):875-882 
37. Mumme J, Eckervogt L, Pielert J, Diakité M, Rupp F, Kern J (2011) Hydrothermal carbonisation of anaerobically digested maize silage. Bioresour Technol 102(19):9255-9260

38. Schneider D, Escala M, Supawittayayothin K, Tippayawong N (2011) Characterization of biochar from hydrothermal carbonization of bamboo. Int J Energy Environ 2(4):647-652

39. Danso-Boateng E, Holdich RG, Wheatley AD, Martin SJ, Shama G (2015) Hydrothermal carbonisation of primary sewage sludge and synthetic faeces: effect of reaction temperature and time on filterability. Environ Prog Sustain Energy 34:1279-1290

40. Qian K, Kumar A, Patil K et al (2013) Effects of biomass feedstocks and gasification conditions on the physiochemical properties of char. Energies 6:3972-3986

41. Murayama E, Vignal A, Morisson M et al (2007) Cloning of ovocalyxin-36, a novel chicken eggshell protein related to lipopolysaccharide-binding proteins, bactericidal permeability-increasing proteins, and plunc family proteins. J Biol Chem 282(8):5273-5286

42. Lima IM, Marshall WE (2005) Granular activated carbons from broiler manure: physical, chemical and adsorptive properties. Bioresour Technol 96:699-706
43. Brunauer S, Deming LS, Deming WE, Teller E (1940) On a theory of the van der Waals adsorption of gases. J Am Chem Soc 62:1723-1732

44. Kaneko K, Ishii C, Ruike M, Kuwabara H (1992) Origin of superhigh surface area and microcrystalline graphitic structures of activated carbons. Carbon 30(7):1075-1088

45. Inyang M, Gao B, Zimmerman A, Zhou Y, Cao X (2014) Sorption and cosorption of lead and sulfapyridine on carbon nanotubemodified biochars. Environ Sci Pollut R 22(3):1868-1876. https ://doi.org/10.1007/s11356-014-2740-z

Publisher's Note Springer Nature remains neutral with regard to jurisdictional claims in published maps and institutional affiliations. 